\title{
Game and Players: Mitochondrial Apoptosis and the Therapeutic Potential of Ursodeoxycholic Acid
}

\author{
Susana Solá1, Márcia M. Aranha', Clifford J. \\ Steer $^{2}$ and Cecília M.P. Rodrigues ${ }^{1 *}$
}

${ }^{1}$ Centro de Patogénese Molecular, Faculty of Pharmacy, University of Lisbon, Lisbon, Portugal

${ }^{2}$ Departments of Medicine and Genetics, Cell Biology, and Development, University of Minnesota Medical School, Minneapolis, MN, USA

\begin{abstract}
Apoptosis represents a universal and exquisitely efficient cellular suicide pathway essential for a variety of normal biological processes ranging from embryonic development to ageing. In fact, tissue homeostasis is dependent on the perfect balance between positive and negative signals that determines the decision between life and death. Therefore, any imbalance can result in a wide range of pathologic disorders associated with unwanted apoptosis or cell growth. During the apoptotic process, the molecular players interact closely with each other in ways relevant to accelerate or interrupt the cellular death process. In addition, two major pathways of apoptosis activation have been recognized as the "intrinsic" mitochondrial pathway and the "extrinsic" death receptor pathway. Although these pathways act independently to initiate apoptosis, a delicate balance and cross-talk between the extrinsic and intrinsic pathways is thought to occur in many cell types. Interestingly, we have shown that ursodeoxycholic acid (UDCA), an endogenous hydrophilic bile acid, is a potent inhibitor of apoptosis by either stabilizing the mitochondrial membrane or modulating the expression of specific upstream targets. Herein, we review the main effectors involved in the death machinery, describe how they interact to regulate apoptosis, and discuss the main pathways that control cell death and survival. Further, we address multiple interesting targets as well as the potential application of UDCA as a therapeutic modality for apoptosis-related disorders.
\end{abstract}

\section{Introduction}

The process of cell death typically follows one of two patterns: necrosis or apoptosis (Bayerdorffer et al., 1993). The first is the consequence of acute metabolic perturbation as it occurs in ischemia/reperfusion or acute drug-induced toxicity. In contrast, apoptosis represents the execution of a death program often initiated by specific stimuli. Nevertheless, it is important to note that, in certain occasions, rather than separate entities, apoptosis and necrosis are frequently the consequence of the same initiating factors and signaling pathways, representing extremes on a continuum of cell death (Bull et al., 1983; Hofmann, 2002).

Apoptosis is an active mechanism by which metazoan organisms quickly eliminate cells in response

*For correspondence: cmprodrigues@ff.ul.pt. to physiological, pathogenic, or cytotoxic stimuli. This genetic program of cell suicide is vital in a wide variety of normal processes ranging from fetal development to ageing, including immune system education, defense against viruses and tissue homeostasis (Reed, 2002). Although apoptosis is a highly regulated mechanism; aberrant levels of apoptosis can occur at any time from embryogenesis to adulthood, resulting in a variety of pathological conditions. In fact, many medical illnesses are attributed directly or indirectly to unregulated apoptosis. An excess of apoptosis may result in T cell depletion, neurodegenerative diseases or hepatocellular degeneration, while impaired apoptosis is frequently observed in tumorigenesis (Daniel, 2000). A better knowledge of the effectors of the death machinery and how they interact to regulate apoptosis defines a potential point of intervention for various human diseases. It is, therefore, not surprising that apoptotic pathways have been a topic of intensive research to identify molecular targets and propose effective therapies in the management of apoptosis-associated disorders.

Interestingly, ursodeoxycholic acid (UDCA), an endogenous hydrophilic bile acid modulates the apoptotic threshold by acting through different molecular pathways. UDCA has been traditionally used for treatment of liver diseases associated with increased levels of apoptosis, including primary biliary cirrhosis, primary sclerosing cholangitis, pediatric cholestatic disorders, cystic fibrosis, and intrahepatic cholestasis associated with pregnancy (Poupon et al., 1994; Rubin et al., 1994). Notably, after conjugation with taurine, UDCA administered in high doses can be delivered to different tissues outside the liver, including the brain. In this regard, it has been demonstrated both in vitro and in vivo that tauroursodeoxycholic acid (TUDCA) can benefit certain acute and chronic neurodegenerative disorders, which are associated with increase levels of apoptosis. TUDCA is a potent neuroprotective agent not only in pharmacologic and transgenic animal models of Huntington's disease (Keene et al., 2002; Keene et al., 2001), but also for acute ischemic and hemorrhagic stroke (Rodrigues et al., 2003a; Rodrigues et al., 2002). Considering its clinical safety, UDCA and/or its conjugate derivates may potentially be powerful therapeutic agents in several human apoptosisassociated injuries.

\section{Molecular mechanisms of apoptosis}

During apoptosis, cells undergo a number of distinct morphological and biochemical modifications, such as cell shrinkage, chromatin condensation, nuclear membrane breakdown and formation of small vesicle-like structures, known as apoptotic bodies. Curiously, the term apoptosis, was first used by Kerr (Kerr et al., 1972) more than 30 years ago, and is derived from Greek to mean "falling or dropping off" as petals or leaves. 
The molecular mechanisms of programmed cell death are highly conserved throughout evolution. Studies in Caenorhabditis elegans (C. elegans) have demonstrated that cell demise is carried out by specific cellular pathways (Hall et al., 1997), suggesting that it may be more "programmed" than initially thought. In fact, cell death in $C$. elegans is regulated only by three genes: ced-3, ced-4 and ced-9 (Fig. 1). Further, Egl-1 blocks the activity of Ced-9, an inhibitor of Ced-4 that complexes with and activates the cysteinic protease Ced-3 (Conradt and Horvitz, 1998).

The apoptosis process can be subdivided into initiation, effector and degradation phases (Kroemer et al., 1995). In mammalian cells, the initiation stage depends on the type of apoptosis-inducing stimulus, whereas the effector and degradation stages are common to all apoptotic processes. Two principal pathways of apoptosis activation that have been recognized include the "intrinsic" mitochondrial pathway and the "extrinsic" death receptor pathway (Fig. 2).

\section{Mitochondrial pathway}

Mitochondria are central to the life cycle of eukaryotic cells. However, in recent years, it has become clear that mitochondria also play a key role during apoptotic cell death (Kroemer, 2003). In mammals, the intrinsic mitochondrial pathway of apoptosis is triggered by several forms of intracellular stress, including oxidative stress, DNA damage, and protein misfolding. This myriad of signals converges on the mitochondrion organelle, leading to membrane permeabilization, release of apoptogenic proteins, and activation of a family of deathinducing cysteine proteases, termed caspases, which cleave a wide array of cellular substrates, leading to cell death. Once activated, caspases amplify the death signal by activating other caspases through proteolytic cleavage. In this regard, several potential targets for modulating mitochondrial apoptosis have been described in ways relevant to the treatment of apoptosis-related human diseases.

Mitochondrial membrane permeabilization. During apoptosis, the process of mitochondrial membrane permeabilization, in particular the collapse of the mitochondrial inner transmembrane potential, appears to represent a point of no return for many cell types (Von

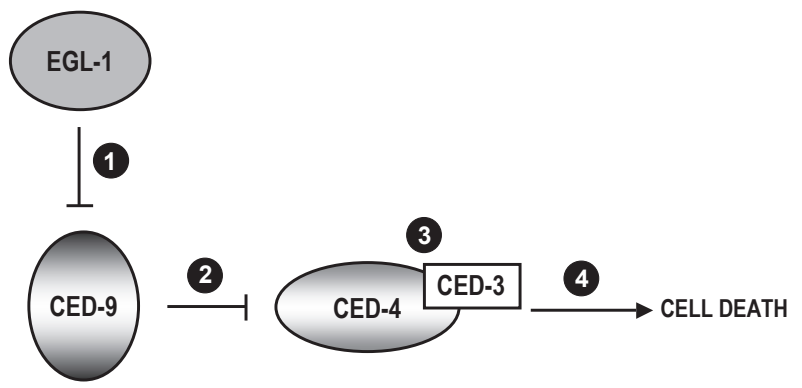

Fig. 1. Apoptotic pathway in C. elegans. EGL-1 blocks the activity of CED-9 (1), an inhibitor of CED-4 (2) that complexes with and activates the cysteinic protease CED-3 (3) to induce cell death (4). Although increasing in complexity from C. elegans to mammals, the fundamental components of the apoptotic system were relatively conserved throughout evolution. $\rightarrow$, induction; - , inhibition.
Ahsen et al., 2000). Although the intricate mechanisms for release of apoptogenic factors from mitochondria to the cytosol are not fully understood, the basic processes have been elucidated (Green and Reed, 1998; Thornberry and Lazebnik, 1998). Following a toxic stimulus, two major pathways have been proposed for release of caspaseactivating proteins from mitochondria. The first is the opening of the mitochondrial permeability transition (MPT) pore; whereas the second is associated with the formation of specific release channels in the outer mitochondria membrane that are regulated by proapoptotic members of the B-cell lymphoma-2 (Bcl-2) family. Importantly, the mechanism by which the bile acid UDCA reduces apoptosis in various cell types, from hepatocytes to neurons, appears to involve an interplay of inhibitory mechanisms for both depolarization and channel-forming activity of the mitochondrial membrane.

Finally, it was recently proposed that mechanisms which regulate structure/function of mitochondria may also play key roles in mitochondrial membrane permeabilization. Nevertheless, the function of proteins involved during the fission and fusion mechanisms of mitochondria during apoptosis are only now beginning to be identified (James et al., 2003).

Mitochondrial permeability transition pore opening. Since the initial characterization of the MPT (Hunter et al., 1976), its onset has been implicated as a key mechanism underlying both necrotic and apoptotic cell death. In fact, it has been proposed that opening of the MPT pore leads to the collapse of the mitochondrial inner transmembrane potential, expansion of the matrix space, and subsequent rupture of the outer membrane (Kroemer et al., 1997; Marchetti et al., 1996; Petit et al., 1996). Inhibitors of the MPT pore, such as cyclosporin A, prevent apoptosis in some systems, supporting a central role for MPT in the apoptotic process (Zamzami et al., 1996). We have also demonstrated that the antiapoptotic effect of UDCA was associated with reduction of the MPT in isolated mitochondria, as well as in primary rat hepatocytes (Rodrigues et al., 1998b; Rodrigues et al., 1999).

$\mathrm{Ca}^{2+}$, inorganic phosphate, alkaline $\mathrm{pH}$, and reactive oxygen species (ROS) are only a few of the many agents that induce MPT by opening high conductance permeability transition pores in the mitochondrial inner membrane. The molecular composition of the MPT pore remains unclear. Nevertheless, it has been shown that the structure spans the mitochondrial inner and outer membranes, and is composed of proteins from both membranes and the matrix (Kroemer and Reed, 2000). It has been suggested that the adenine nucleotide translocator (ANT), located in the mitochondrial inner membrane, is an essential component of the MPT pore (Brustovetsky and Klingenberg, 1996). In addition, the voltage-dependent anion channel (VDAC) of the outer mitochondrial membrane and cyclophilin $D$ from the matrix (Crompton et al., 1998) were also proposed to be part of the MPT pore complex. VDAC has the important role of making the outer membrane permeable to metabolites that must move in and out of mitochondria, such as ATP, ADP, and respiratory substrates. Cyclophilin $\mathrm{D}$ is a peptide prolyl cis-trans isomerase in the matrix space that appears to associate with the MPT pore 


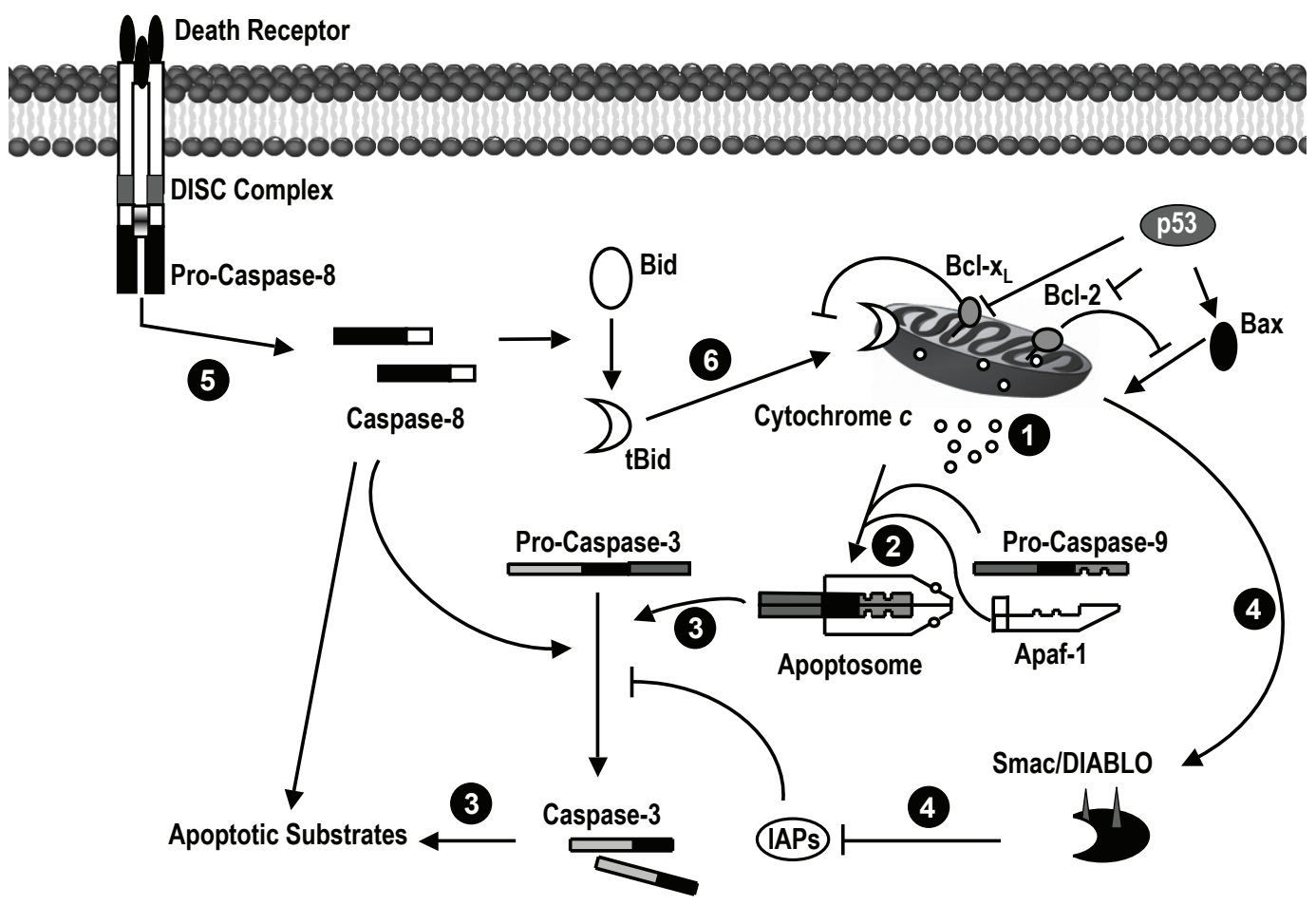

Fig. 2. Major apoptotic pathways in mammalian cells. The mitochondrial pathway is characterized by cytochrome $c$ release from the mitochondria (1), which then associates with Apaf-1 and caspase 9 and apoptosome formation (2). The subsequent proteolytic cascade leads to the cleavage of DNA and apoptotic substrates (3). Smac/DIABLO is also released into the cytoplasm, where it binds IAPs reducing their inhibition of caspases (4). The death receptor pathway is activated by binding of a ligand to the death receptor inducing receptor dimerization and formation of the DISC complex that activates caspase-8 (5). A cross-talk between the two pathways occurs by cleavage of Bid to generate tBid, a highly proapoptotic fragment that causes the release of cytochrome $c$ (6). See text for more details. $\rightarrow$, induction; $\multimap$, inhibition.

complex, conferring cyclosporine A sensitivity. Moreover, there are other proteins that may bind to and regulate the MPT pore opening, including members of the Bcl-2 family, such as Bax (Tsujimoto and Shimizu, 2002), and viral proteins (Vprs), such as Vpr from HIV-1 (Halestrap and Brennerb, 2003). Thus, VDAC may be an essential player in apoptosis, contributing to the release of various apoptogenic proteins from the intermitochondrial space to the cytosol, and thereby promoting cell death (Zoratti and Szabo, 1995).

Bcl-2 family regulation. Since the discovery that certain Bcl-2 family proteins could form channels of discrete conductance across synthetic lipid membranes, they have been prime candidates for the formation of apoptogenic factor releasing channels (Minn et al., 1997; Schendel et al., 1999). In fact, Bcl-2-related proteins constitute one of the biologically most relevant classes of apoptosisregulatory gene products, acting at the effector stage of apoptosis. Bcl-2 was first identified as a proto-oncogene in follicular B-cell lymphoma. In lymphoma cells, the bcl2 gene was found at the breakpoint of the translocation between chromosomes 14 and 18, where the gene is under control of the immunoglobulin heavy chain intron enhancer (Tsujimoto et al., 1985). Subsequently, Bcl2 was identified as a mammalian homologue to the apoptosis repressor Ced-9 in C. elegans.

There are three groups of Bcl-2-like proteins (Fig. 3). Group I is constituted by proteins that contain four conserved Bcl-2 homology $(\mathrm{BH})$ domains, $\mathrm{BH} 1, \mathrm{BH} 2$,
$\mathrm{BH} 3$, and $\mathrm{BH} 4$, and have a $\mathrm{C}$-terminal hydrophobic tail, which allows them to anchor to the cytosolic surface of intracellular membranes (e.g. Bcl-2, Bcl- $\mathrm{x}_{\mathrm{L}}$ ) (Kaufmann and Hengartner, 2001). Members of group II differ from group I by the absence of the $\mathrm{BH} 4$ domain (e.g. Bax, Bak), while group III has a higher level of heterogeneity, comprising proteins with only the $\mathrm{BH} 3$ domain (e.g. Bad, Bid, Bim, Bik, Hrk) (Cory et al., 2003). Interestingly, BH domains have been shown to mediate protein interactions that form either homo- or hetero-complexes (Yin et al., 1994).

Bcl-2 family members regulate the mitochondrial apoptotic pathway by either a positive or negative fashion (Sorenson, 2004). It was proposed that antiapoptotic members of multi-domain Bcl-2 family proteins (e.g. Bcl2, Bcl- $\left.\mathrm{x}_{\mathrm{L}}, \mathrm{Bcl}-\mathrm{w}, \mathrm{Mcl}-1, \mathrm{~A} 1\right)$ have a modulatory action, while proapoptotic members (e.g. Bax, Bak) would be effectors of the integration process. Further, proapoptotic $\mathrm{BH} 3-o n l y$ proteins may function as cell sensors involved in processing the different signals for life and death. While some members of this family are constitutively localized in the outer mitochondrial membrane, other family members have been identified in other subcellular localizations, including the endoplasmic reticulum, cytosol and bound to microtubules. The subcellular localization of Bcl-2 family members is controlled through such processes as heterodimerization, phosphorylation and proteolysis, among others. The mechanism(s) by which Bcl-2 family members regulate membrane permeability remains controversial. The three most popular theories 

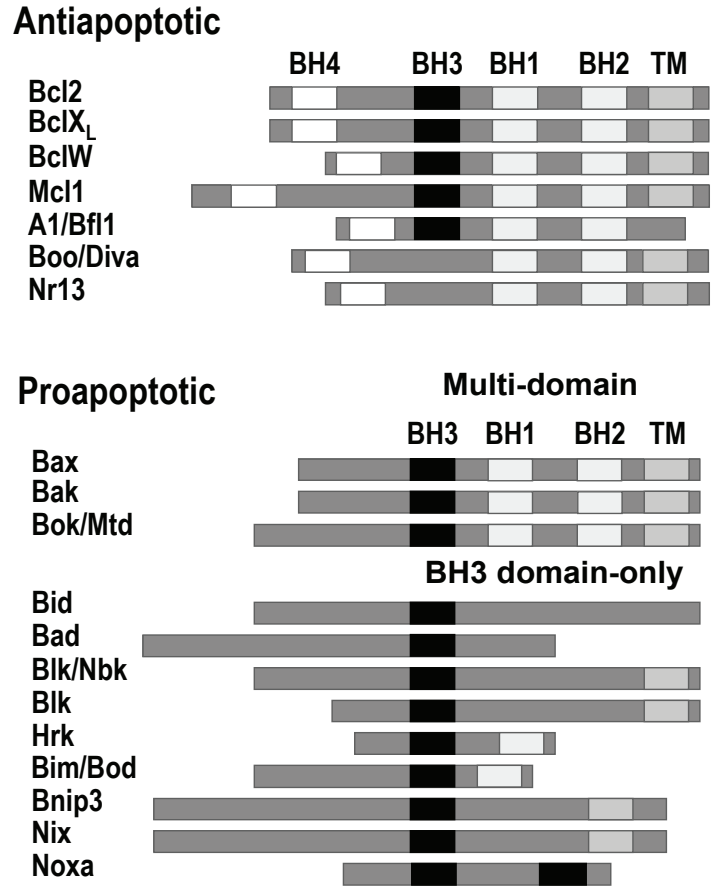

Fig. 3. Classification of Bcl-2 family members according to their function Antiapoptotic members have four $\mathrm{BH}$ domains, $\mathrm{BH} 1-4$, while proapoptotic members have three $\mathrm{BH}$ domains, $\mathrm{BH} 1-3$; or only the $\mathrm{BH}$ domain $(\mathrm{BH} 3-$ only proteins). $\mathrm{BH}, \mathrm{Bcl}-2$ homology; $\mathrm{TM}$, transmembrane.

postulate that they either form de novo protein channels in membranes, interact with and regulate pre-existing mitochondrial membrane pores, or alter the membrane lipid order to produce pores (Sharpe et al., 2004).

Baxand Bak are normally located, as monomers, either in the cytosol or loosely attached to the outer mitochondrial membrane. Following induction of apoptosis, these proteins undergo a conformational change, oligomerize, and translocate to the outer mitochondrial membrane (Hsu et al., 1997). In fact, protein-protein interactions and/ or conformational alterations of Bax and Bak proteins may expose their hydrophobic domains, leading to a change in subcellular localization (Antonsson and Martinou, 2000). After insertion into the mitochondrial lipid membrane, Bax and/or Bak form a hydrophobic pore, triggering the release of apoptogenic factors, such as cytochrome $c$ (Epand et al., 2002; Eskes et al., 1998; Finucane et al., 1999). Curiously, antiapoptotic members of the Bcl-2 family, such as $\mathrm{Bcl}-2$ and $\mathrm{Bcl}-\mathrm{x}_{\mathrm{L}}$, reside in the mitochondrial membrane and interact with Bax through the $\mathrm{BH} 1$ and $\mathrm{BH} 2$ domains, preventing pore formation and release of apoptogenic proteins (Antonsson et al., 1997). Moreover, the proapoptotic member Bad binds and inactivates Bcl-2 and $\mathrm{Bcl}-\mathrm{x}_{\mathrm{L}}$ (Datta et al., 1997), while BH3-only proteins link the death receptor and the mitochondrial pathways of apoptosis (Luo et al., 1998). Bax and Bcl-2 are also thought to induce modulation of the MPT pore (Vieira et al., 2000). However, others have demonstrated that Bax does not have a major role in regulating the MPT pore in isolated mitochondria (De Marchi et al., 2004).

Interestingly, experimental evidences have indicated that UDCA may also interfere with Bcl-2 family members, decreasing mitochondrial-associated Bax protein levels (Rodrigues et al., 1998a). UDCA directly binds and stabilizes the mitochondrial membrane, thus preventing the insertion of Bax in the mitochondria (Rodrigues et al., 2003b). Further, we have recently demonstrated that this hydrophilic bile acid induces expression of Bcl-2 and decreases Bax levels in a caspase-independent manner (Solá et al., 2003b). Finally, other approaches have been proposed for exploiting Bcl-2 family proteins for therapeutic gain. For example, antiapoptotic Bcl-2 family genes have been the target for cytoprotection in animal models for the potential treatment of several human brain injuries (Dubois-Dauphin et al., 1994; Kostic et al., 1997). In contrast, molecules have been reported that bind to antiapoptotic $\mathrm{Bcl}-2$ or $\mathrm{Bcl}-\mathrm{x}_{\mathrm{L}}$ and promote apoptosis of cancer cells (Degterev et al., 2001; Tzung et al., 2001). Although these compounds are only in development stage, they provide proof-of-concept that it may be possible to derive sufficiently potent compounds for antagonizing the functions of selected members of the Bcl-2 family in vivo.

Release of apoptogenic factors. During apoptosis, mitochondrial outer membrane permeabilization results in release of cell death-activating factors to the cytosol, including cytochrome $c$, second mitochondria-derived activator of caspases/direct IAP binding protein with low pl (Smac/DIABLO), apoptosis-inducing factor (AIF), and endonuclease G (Endo G) (Parone et al., 2002). Once released, these proteins activate caspases, which in turn cleave a wide array of cellular substrates, ultimately resulting in demise of the cell.

Cytochrome $c$ is an electron carrier in the respiratory chain. Nevertheless, it is also a key factor in opening the door to cell death. Once in the cytosol, cytochrome $c$ binds with high affinity to the scaffolding protein known as apoptotic protease-activating factor-1 (Apaf-1) (Fig. 4). Cytochrome $c$ induces conformational changes in Apaf-1, mediated by cytosolic dATP and/or ATP, allowing the homo-oligomerization of Apaf-1 (Zou et al., 1997). The inactive form of caspase- 9 , procaspase- 9 , is then recruited to the complex through caspase-activating and -recruiting domains (CARD) and CARD-CARD interactions. The apoptosome complex rapidly processes procaspase- 9 into the mature and active form, caspase9 , which in turn activates other caspases that function as downstream effectors of the cell death program (Thornberry and Lazebnik, 1998). The fundamental components of this complex have been conserved throughout evolution of metazoan organisms (Rodriguez et al., 1999). Nevertheless, a novel role for cytochrome $c$ was recently described. In fact, upon induction of apoptosis, cytochrome $c$ gradually accumulates in the nucleus, inducing chromatin condensation and release of acetylated histones (Nur et al., 2004).

The inhibitors of apoptosis proteins (IAPs) are normally present in the cytosol, directly inhibiting caspases (Bratton et al., 2001). Cells have evolved an interesting mechanism to overcome the effects of these inhibitory proteins. In fact, a novel human protein Smac, and its murine homologue DIABLO has been recently described as a promoter of apoptosis by eliminating IAP inhibition of caspases (Du et al., 2000; Ekert et al., 2001). Smac/DIABLO is synthesized as a 239 amino acid precursor protein which is targeted to the mitochondria via its $N$-terminal domain. 


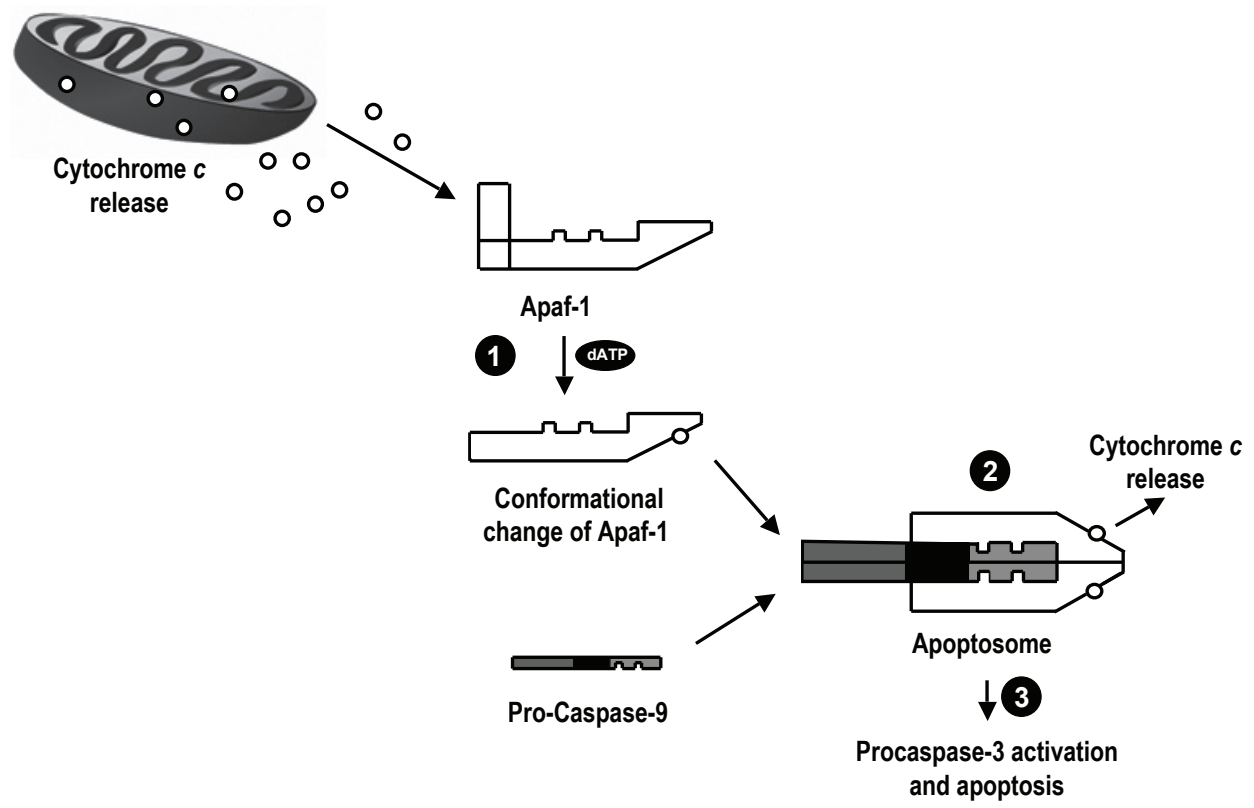

Fig. 4. Formation of the apoptosome. Cytochrome $c$ induces conformational changes in Apaf-1, mediated by cytosolic dATP (1), thereby allowing the homooligomerization of Apaf-1. Subsequently, the apoptosome complex processes procaspase-9 into the mature and active form caspase-9 (2), which in turn activates procaspase-3 and triggers apoptosis (3). $\rightarrow$, induction.

Once in the intermembrane space, the mitochondrial localization sequence is proteolytically removed, exposing an IAP-binding motif. After mitochondrial membrane permeabilization, mature Smac/DIABLO is released into the cytoplasm, where it binds IAPs and reduces their inhibition of caspases. It is thought that Smac/DIABLO directly competes with caspases for the IAP binding site or, somehow, interferes with the caspase/IAP interaction. In addition to these effects, Smac/DIABLO may also be a proapoptotic molecule by other mechanisms, possibly involving the apoptosome complex (Roberts et al., 2001). Recently, the mitochondrial serine protease HtrA2/Omi was shown to interact with IAPs, inhibiting their function and promoting cell death through an increase of caspase activity (Verhagen et al., 2002).

The link between mitochondrial membrane permeabilization and nuclear degradation has been established through the activity of AIF (Susin et al., 1999). Although heat shock protein 70 (hsp70) inhibits AIF activity by physical interaction (Ravagnan et al., 2001), the nuclear translocation of AIF appears to be a general pathway of apoptosis in mammalian cells. Furthermore, AIF has NADH oxidase activity, scavenging and protecting cells from oxidative stress (Miramar et al., 2001). The $\mathrm{N}$-terminal domain of AIF containing the mitochondrial localization sequence is cleaved when AIF is imported into the mitochondrial intermembrane space, giving rise to a mature form of the protein. During the apoptosis process, AIF is translocated from the mitochondria to the cytosol, and subsequently to the nucleus where it induces peripheral chromatin condensation and high molecular weight DNA fragmentation ( $50 \mathrm{kbp}$ ) (Susin et al., 1999), via proteolytic activation of a nuclear endonuclease. Currently, the mechanism of AlF-induced cell death is considered to be independent of caspases. However, several studies have also demonstrated that the release of AIF from the intermembrane space of the mitochondria may be caspase-dependent (Cande et al., 2004). However, developmental studies seem to argue in favor of the first hypothesis, since the effect of AIF in very early stages of mammalian development is essentially a caspase-independent mechanism (van Gurp et al., 2003). It is important to note that at odds with the mitochondrialmediated pathway, apoptosis driven by the nucleus is often a caspase-independent process.

Finally, Endo G, initially thought to be involved in the replication of the mitochondrial genome, is also translocated from the mitochondria into the nucleus after mitochondrial membrane permeabilization, cleaving DNA in a caspase-independent manner (Li et al., 2001; van Loo et al., 2001). It was recently demonstrated that a deoxyribonuclease inhibitor significantly reduces the nuclear activity of a recombinant Endo $G$ protein, and that the endogenous silencing of Endo $G$ by RNA interference inhibits apoptosis levels in primary rat hepatocytes (Ishihara and Shimamoto, 2006). Notably, it has been suggested that Endo $G$ plays a critical role in the induction of apoptotic neuronal excitotoxicity, such as in cerebral ischemia. Endo $\mathrm{G}$ is predominantly colocalized with AIF in ischemic mice brain, and spatially related with DNA fragmentation (Lee et al., 2005). The type of DNA fragmentation induced by Endo $G$ is still controversial (Li et al., 2001). Some studies have indicated that the nuclear translocation of Endo $G$ is not sufficient for the induction of oligonucleosomal DNA fragmentation (Park et al., 2005). Further investigation is required to elucidate the interaction of Endo $G$ and other effectors in nuclear apoptosis. 


\section{Caspase activation}

The executioners of the apoptosis process are a group of cysteinic proteases that cleave their substrates at the site of an aspartate residue, and are termed cysteinyl aspartate-specific proteases or caspases (Thornberry and Lazebnik, 1998). The caspases substrates include a wide range of substrates, such as Bid, the poly(ADPribose) polymerase (PARP), lamins, among many others. The critical involvement of caspases in apoptosis was first documented in 1993, when Ced-3 was found to play a central role in programmed cell death of $C$. elegans (Yuan et al., 1993). These proteins are synthesized as inactive zymogens or precursor forms, and must undergo a process of activation during apoptosis. Therefore, based on their order of activation, caspases are classified into two families of the initiator caspases (e.g. caspase-1, -2, $-8,-9,-10)$ and the effector caspases (e.g., caspase-3, -4 , $-5,-6,-7,-11,-12,-13)$ (Shi, 2002). The inactive form of the caspase zymogen consists of an $N$-terminal prodomain in addition to large and small subunits. These long prodomains contain specific protein-protein interaction motifs, named CARD. Curiously, although many of the CARD-family proteins can interact with caspases to either trigger or suppress apoptosis, structural studies indicate that CARD-CARD protein interactions do not represent compelling small-molecule drug targets.

Through the $N$-terminal domains, initiator caspases interact with adaptor proteins that recruit them to specific "death complexes", which are large multiprotein complexes mediating caspase activation. In mammals, the death complexes include the apoptosome in the mitochondrial pathway, and/or the Fas associated death domain (FADD)/caspase-8 death-inducing signal complex (DISC) in the death receptor pathway. In response to an upstream apoptotic stimulus, initiator caspases also known as "apical caspases" undergo a complex course of autocatalytic processing and activation, requiring several auxiliary factors (Shi, 2002; Shi, 2004). In fact, the autocleavage of the intrachain that occurs in initiator caspases appears to have only a modest effect on its catalytic activity (Srinivasula et al., 1998). For example, procaspase- 9 needs the apoptosome assembly to enhance the catalytic activity of caspase- 9 .

Even with removal of the prodomain, the crucial step in activation of initiator caspases is formation of a homodimer of the zymogen rather than proteolytic cleavage (Fig. 5). The mature form of caspases are heteromeric $\alpha_{2} \beta_{2}$ tetramers, bearing catalytic activity with two identical small and large subunits (Degterev et al., 2003). In addition, the subsequent cleavage within the interdomain linker stabilizes the apical caspase dimmers. After activation, initiator caspases specifically cleave the intrachain of effector caspases zymogens, enhancing their catalytic activity by several orders of magnitude. In the apoptotic mitochondrial pathway, the initiator caspase9 activates the effector caspase-3, which in turn can activate other effectors towards cell death (Thornberry and Lazebnik, 1998). The downstream effectors activated by caspase- 3 include caspase- 6 and -7 , and endonucleases, such as the deoxyribonuclease (DNAse) acinus and caspase activated deoxyribonuclease (CAD)/ DNA fragmentation factor 40 (DFF40). Acinus is cleaved by caspase-3, giving rise to an active DNAse, responsible for chromatin condensation without DNA fragmentation. Curiously, CAD/DFF40 normally resides in the nucleus, in a complex with its endogenous chaperone, the inhibitor of CAD (ICAD)/DFF45. The cleavage of ICAD/DFF45 by caspase-3 releases CAD/DFF40 (Sakahira et al., 1998), which in turn cleaves DNA in internucleosomal fragments ( $200 \mathrm{bp}$ ). During apoptosis, caspase-3 is also responsible for the proteolytic cleavage of PARP (Rosen and Casciola-Rosen, 1997) into two inactive fragments of 24 and $85 \mathrm{kDa}$. The $\mathrm{N}$-terminal fragment (p24) remains in the nucleolus, retains its DNA-binding activity and inhibits the catalytic activity of uncleaved PARP, while impairing DNA repair.

In the mitochondrial pathway, caspase-9 was considered the initiator caspase and the release of cytochrome $c$ is essential for the activation of the caspase cascade (Thornberry and Lazebnik, 1998). However, it was recently demonstrated that in response to cell stress, activation of caspase-2 is required for mitochondria permeabilization (Lassus et al., 2002). Similar results were reported by two other groups, which demonstrated that caspase-2 can directly induce release of cytochrome $c$, Smac/DIABLO and AIF from the mitochondria (Guo et al., 2002; Robertson et al., 2002). Another group also reported that caspase- 2 in the nucleus signals cytochrome $c$ release from mitochondria (Paroni et al., 2002). Using different systems and cell types, all of these studies suggest that caspase- 2 , not caspase- 9 , is the apical caspase in the proteolytic cascade initiated by stress signals. If correct, this model might help to explain the occurrence of apoptosis in cells lacking Apaf-1 or caspase-9 (Zheng et al., 1999). Further, overexpression of Bcl-2 in lymphocytes, but not the absence of Apaf-1 and caspase- 9 , has been shown to significantly increase the number of cells (Marsden et al., 2002).

In addressing the pivotal position of the mitochondrial pathway of apoptosis, recent studies have also suggested an endoplasmic reticulum (ER) stress-mediated pathway that bypasses mitochondria to directly activate caspases. Although not fully understood, this pathway appears to involve disruption of calcium homeostasis as well as caspase-12 activation (Lamkanfi et al., 2004). Interestingly, during apoptosis, translocation of the Bcl-2 protein, Bim, to the ER can mediate ER-stress signaling for activation of caspase-12 (Morishima et al., 2004). Also, caspase activation does not always lead to cell death and may, in fact, be required for cell differentiation. The function of caspase- 1 and -5 is thought to be involved in processing precursors of certain inflammatory cytokines. Caspase1 also plays a key role during apoptosis of neurons and macrophages. It was recently demonstrated that caspase1 is an upstream positive regulator of caspase-6-mediated cell death in primary human neurons (Guo et al., 2006). Further, caspase-1 promotes apoptosis in cancer cells (Feng et al., 2005). In addition, the expression of caspases is spatially and temporally regulated, depending on the cell type and development stage. Curiously, caspase-2, -10 and -14 mRNAs are abundantly present in various embryonic tissues, but are poorly expressed in adult tissues, suggesting a specific role of these caspases in fetal development. On the other hand, it has been shown 

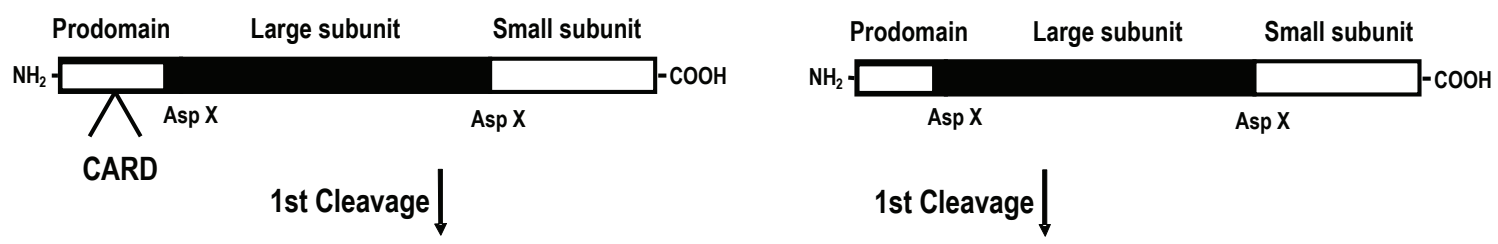

1st Cleavage

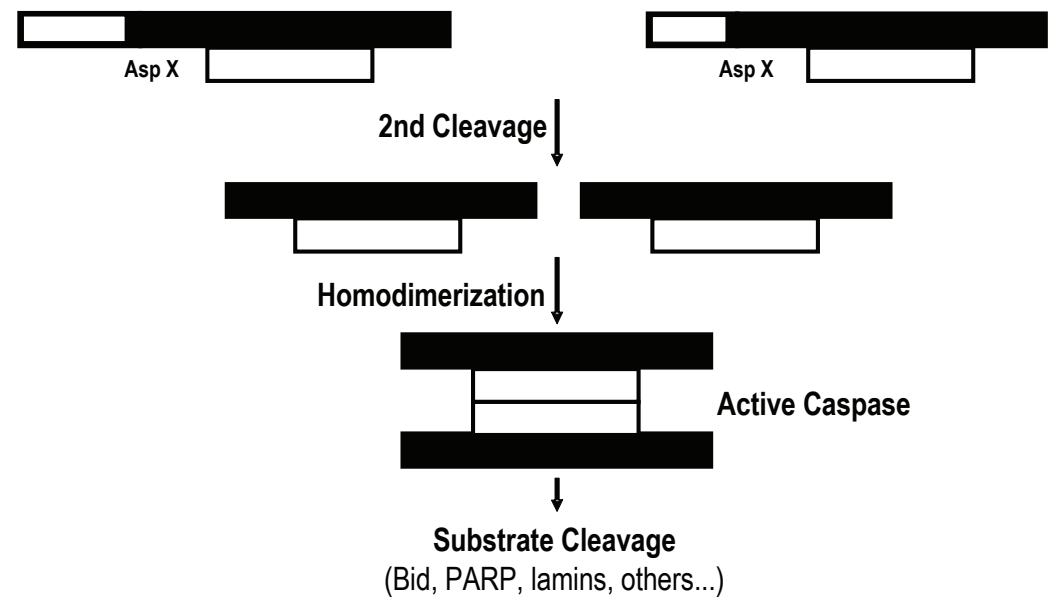

Fig. 5. Activation of caspases. After proteolytic cleavage of caspases, the prodomain is removed. Nevertheless, the crucial step in activation of initiator caspases appears to be the formation of a homodimer of the zymogen rather than the proteolytic cleavage. $\rightarrow$, induction.

that the cellular context plays an important role in defining the consequences of caspase activation (Abraham and Shaham, 2004). Finally, recent investigations have demonstrated caspase-independent pathways leading to cell death, where the regulation of the mitochondrial integrity is still a key event (Donovan and Cotter, 2004), such as in AIF- and Endo G-induced apoptosis.

Among the potential apoptosis-based drug targets, strategies that target caspases are at the forefront for blocking apoptosis in numerous diseases. For example, caspase-1 knockout mice show marked resistance to endotoxin-induced sepsis (Li et al., 1995), demonstrated less tissue loss in stroke models (Bergeron et al., 1998), and have slower disease progression in a mouse model of Huntington's disease (Ona et al., 1999). Furthermore, potent non-peptidyl small-molecule inhibitors of certain caspases have been described (Lee et al., 2001), raising hopes that molecules with pharmaceutical properties can be identified and developed for clinical use. Nevertheless, it is important to note that their mechanism of action targets events that occur subsequent to the damaging effects of mitochondrial membrane permeabilization.

\section{Death receptor pathway}

Life and death decisions of the cell are significantly influenced by components of the extracellular matrix, which can change dynamically during differentiation, development and other tissue-remodeling events. The classical death receptor pathway of apoptosis is initiated by the binding and activation of transmembrane death receptors, leading to the recognition of DISC (Krammer, 1999). The function of this pathway was first typified by members of the tumor necrosis factor receptor (TNFR) family, including the Fas/CD95/APO-1 and TNF- $\alpha$ receptors (Nagata and Golstein, 1995), after binding of the proapoptotic Fas ligand (FasL) and TNF- $\alpha$ (Brunner et al., 1995). In fact, binding of trimeric ligands triggers recruitment of adaptor proteins to the death domain of the receptor. These include FADD for the TNF and Fas pathway or receptor interacting protein (RIP) and RIPassociated ICH-1/Ced-3-homologous protein with a death domain (RAIDD) for the TNF-R1 (Blagosklonny, 2000). The adaptor proteins then recruit procaspases, which are then combined into the enzymatically active heterotetramers. FADD was shown to contain two death effector domains that recruit caspase-8 or its enzymatically inactive homologue, the Fas inhibitor FADD-like interleukin-1 $\beta$ converting enzyme (FLICE)-inhibitory protein (FLIP) (Krueger et al., 2001). Caspase-8 is the dominant death receptor-activated caspase, and is recruited by the TNFrelated apoptosis-inducing ligand (TRAIL) receptors, Fas/ CD95, and TNF-R1. Indeed, it was already established that TRAIL induces apoptosis of cancer cells through mechanisms that involve the activation of caspase-8 (Lacour et al., 2001). Differences in the ratios of deathinducing receptors or other factors influence the selective vulnerability of tumor cells to TRAIL, promoting preclinical efforts to use recombinant protein fragments of TRAIL for cancer therapy. Active caspase- 8 then promotes cleavage of various downstream caspases, including caspase-3, -6 and -7 , which in turn execute apoptosis by degrading hundreds of regulatory proteins. In addition, caspase10, which was primarily implicated in TRAIL-mediated death, may contribute, but apparently is not decisive in TRAIL and Fas signaling, while TNF-R1 seems to recruit 
caspase-2 via RIP and RAIDD adaptor proteins (Daniel, 2000).

Importantly, active caspase-8 cleaves the $\mathrm{Bcl}-2$ family member Bid to generate an active truncated Bid (tBid) fragment, allowing the cross-talk between death receptor and mitochondrial pathways of cell death ( $\mathrm{Li}$ et al., 1998; Luo et al., 1998). In fact, tBid acts as a cofactor for Bax and Bak, inducing their conformational change and subsequent mitochondrial translocation (Eskes et al., 2000; Roucou et al., 2002). Furthermore, tBid was shown to interact with and inhibit the antiapoptotic protein $\mathrm{Bcl}-2$ in the outer mitochondrial membrane (Kim et al., 2000). Other groups have demonstrated that both full Bid and tBid may directly induce mitochondrial membrane permeabilization and cytochrome $c$ release (Goonesinghe et al., 2004). In fact, targeting of Bid to mitochondria is facilitated by $\mathrm{N}$-myristosylation at a site that becomes available for modification after caspasemediated processes. Interestingly, in response to different conditions of stress, the activation of caspase8 by the death receptor pathway is the key to activate the mitochondrial apoptosis machinery, as an amplifying loop of cell death. This coordination between the extrinsic and intrinsic apoptotic pathways reinforces the critical role of the mitochondrial organelle during programmed cell death. In this regard, UDCA was shown to partially prevent the death receptor pathway of apoptosis in primary mouse hepatocytes co-cultured with fibroblasts that express the Fas ligand, possibly by its direct effects at the mitochondrial membrane (Azzaroli et al., 2002).

\section{Survival pathways and apoptosis}

There are several antiapoptotic pathways that tightly regulate apoptosis. For example, antiapoptotic members of the Bcl-2 family largely contribute to reducing cell death, mainly by interacting with proapoptotic proteins and inhibiting cytochrome $c$ release from mitochondria. In addition, dephosphorylated Bad is normally located in the mitochondria, interacting with and inhibiting the antiapoptotic proteins, $\mathrm{Bcl}-2$ and $\mathrm{Bcl}-\mathrm{X}_{\mathrm{L}}$. Upon survival signals, Bad is phosphorylated and sequestered by the 14-3-3 protein from its mitochondrial targets (Datta et al., 1997; del Peso et al., 1997).

Cell surviving pathways are triggered by a wide range of agents, including cytokines from the TNF superfamily (Gaur and Aggarwal, 2003), and bile acids (Rust et al., 2000), among others. Survival stimuli generally mediate intracellular signaling through activation of transmembrane receptors, which either possess intrinsic tyrosine kinase activity (e.g. the insulin-like growth factor I receptor), are indirectly coupled to tyrosine kinases (e.g. integrins), or are indirectly coupled to seven transmembrane $G$ protein-coupled receptors (e.g. the lysophosphatidic acid receptor $\left.L P_{A 1} / V Z-1\right)$ (Clark and Brugge, 1995). Importantly, attractive protein-kinase targets for inducing apoptosis can also be used to treat cancer.

Recently, the ability of trophic factors to promote survival has been attributed, at least in part, to the phosphatylinositide $3^{\prime}-\mathrm{OH}$ kinase $(\mathrm{PI} 3 \mathrm{~K}) / \mathrm{c}-\mathrm{Akt}$ kinase cascade. In fact, activation of transmembrane receptors results in the recruitment of PI3K isoforms to the inner surface of the plasma membrane as a result of ligand- regulated protein-protein interactions (Toker and Cantley, 1997). In fact, Akt family kinases become activated downstream of several growth-factor receptors and oncoproteins that trigger the activation of PI3K. Further, UDCA and TUDCA were shown to protect mitochondriacontrolled apoptosis by activating the PI3K survival pathway in primary rat hepatocytes and primary rat cortical neurons, respectively (Schoemaker et al., 2004; Solá et al., 2003a).

Several targets of the PI3K/c-Akt signaling pathway have been recently identified (Datta et al., 1999). PI3K phosphorylates the $3-\mathrm{OH}$ position of the inositol ring in phosphatidylinositol (Ptdlns), generating Ptdlns $(3,4) \mathrm{P}_{2}$ and Ptdlns $(3,4,5) \mathrm{P}_{3}$ that bind to the pleckstrin homology domain of phosphoinositide-dependent kinase 1 (PDK1), which in turn activates downstream targets such as Akt and glucocorticoid-inducible kinase (SGK) (Park et al., 1999). Akt inhibits apoptosis by inactivating proapoptotic proteins such as Bad, caspase-9, forkhead and Nur77, and by activating antiapoptotic proteins, such as nuclear factor- $\mathrm{KB}(\mathrm{NF}-\mathrm{KB})$ and $\mathrm{CAMP}-$ response element-binding protein (CREB) (Datta et al., 1997; del Peso et al., 1997).

$\mathrm{NF}-\mathrm{kB}$ is a ubiquitous transcription factor that mediates a variety of proinflammatory responses (Ghosh and Karin, 2002). In unstimulated cells, NF-KB is sequestered in the cytoplasm by NF-KB inhibitor proteins (IKBS), which prevent its translocation to the nucleus. In response to various stimuli, including cytokines and reactive oxygen species, specific kinases phosphorylate $I \kappa B$, leading to its proteolysis and subsequent dissociation from NF-KB. In the nucleus, NF-KB binds to specific response elements in the promoter of target genes, including proinflammatory cytokines but also antiapoptotic $\mathrm{Bcl}-2$ elements. Thus, activation of NF-kB promotes either cell injury or protection. Curiously, Akt modulates NF-kB activity by phosphorylating IKB kinase- $\alpha$ (Ozes et al., 1999), and phosphorylates proapoptotic Bad, thereby blocking it from binding and inactivating antiapoptotic $\mathrm{Bcl}-2$ and $\mathrm{Bcl}-$ $X_{L}$ (Datta et al., 1997). Indeed, the NF-KB hyperactivity has been observed in several types of cancer. Some agents that have antitumor activity interfere with NF-KB activity (Sporn et al., 2001). These compounds should be explored for their ability to sensitize tumors to apoptosis, in addition to their ability to treat inflammatory diseases in which NF-kB has been implicated. Proteosome inhibitors that are now in clinical trials for cancer might exert, at least in part, their antitumor activity through effects on $\mathrm{NF}-\kappa \mathrm{B}$, by preventing degradation of $\mathrm{I} \mathrm{KB}$ (Adams et al., 2000).

Other studies have suggested that Akt also inhibits apoptosis at the premitochondrial level, by inhibiting cytochrome $c$ release and alteration of mitochondrial membrane potential (Gottlob et al., 2001; Kennedy et al., 1999). In addition, Akt was shown to suppress both conformational change and mitochondrial translocation of Bax (Tsuruta et al., 2002), as well as to phosphorylate and inactivate caspase-9 (Cardone et al., 1998). The mitogenactivated protein kinase (MAPK) pathway also plays a critical role in promoting cell survival. Curiously, another mechanism by which UDCA may prevent apoptosis in hepatocytes is via activation of MAPK survival signal 
(Qiao et al., 2002). MAPK-activated kinases, the Rsks, catalyze the phosphorylation of Bad in vitro and in vivo. Rsks are also known to activate the transcription factor CREB, which in turn promotes cell survival (Bonni et al., 1999).

Cells are also believed to acquire resistance to apoptosis by overexpression of IAPs. Following their initial discovery in the baculoviral genome, IAPs were identified in species ranging from yeast, nematodes, flies, and man. Several human IAPs have been described, including c-IAP1, c-IAP2, NAIP, Survivin, XIAP, Bruce, ILP-2, and Livin. The IAP family members are defined by one or more repeats of a highly conserved 70 amino acid domain, termed the baculovirus IAP repeat (BIR), located at the amino-terminus. As their name implies, IAP family proteins are able to inhibit apoptosis induced by a variety of stimuli. This mechanism is mainly mediated by direct binding and inhibition of certain caspases. Indeed, XIAP, C-IAP1, C-IAP2 and Survivin directly bind and inactivate caspase-3, -7, and -9 (Nachmias et al., 2004).

Some IAPs are overexpressed in cancer and are associated with resistance to apoptosis. Among these are Survivin and melanoma IAP (MLIAP), also known as Livin/KIAP, which are expressed at low levels in normal adult tissues, but are found at higher levels in certain types of tumor (Ambrosini et al., 1997; Vucic et al., 2000). Moreover, antisense experiments have also validated certain IAPs as potential drug targets for cancer (Chen et al., 2000). Consequently, therapeutic strategies are being developed to interfere with IAP function, thus releasing caspases to induce apoptosis of cancer cells. In addition, IAPs are a novel target for gene therapy to reduce neuronal cell loss following stroke or other brain injuries. In this respect, hereditary mutations in the gene that encodes the IAP-family member NAIP (neuronalapoptosis inhibitory protein) have been described in some patients with spinal muscular atrophy, a motor-neuron degenerative disease.

Among the human IAPs, XIAP is the bestcharacterized member, having three BIR domains, which are functionally distinct. BIR 3 inhibits caspase-9 by binding to an area that is exposed after caspase- 9 cleavage, while the region encompassing BIR 1 and BIR 2 was shown to act on caspase- 3 and -7 (Takahashi et al., 1998). Interestingly, much like Smac/DIABLO, the protein Grim has been described as an antagonist of IAPs, interfering with inhibition of caspases (Silke et al., 2004). Finally, recent studies have discovered other functions for IAPs. Survivin has been shown to play a role in mitosis, mainly in microtubule organization (Li et al., 1999), while c-IAP1 and c-IAP2 are an integral part of the type-2 TNFreceptor complex (Rothe et al., 1995).

\section{Cell cycle and apoptosis}

Apoptosis and proliferation are intimately coupled. Since tissue homeostasis is dependent on the precise balance between cell proliferation and cell death, some cell cycle regulators modulate both processes. Transcription factors of the E2F family regulate the expression of many genes that are necessary for normal proliferation, in a cell cycle-specific manner (Dyson, 1998). Nevertheless, one member of this family, E2F-1, has also been implicated in the induction of apoptosis (Nevins, 1998). E2F-1 is typically bound to the unphosphorylated retinoblastoma protein (pRb) (Dyson, 1998). However, under certain stress conditions and during the cell cycle, $\mathrm{pRb}$ is inactivated and/or degraded (Mittnacht, 1998), releasing E2F-1 to transactivate its target genes. At least three different mechanisms have been proposed to play a role during E2F-1-mediated apoptosis, including the inhibition of antiapoptotic signaling, the stabilization of the tumor suppressor protein, p53, via the transcription $\mathrm{p} 14^{\mathrm{ARF}}$, and the transcriptional activation of the p53 homologue p73 (Phillips and Vousden, 2001). Under physiological conditions, the cooperation between all these pathways is likely to contribute to E2F-1-induced death. In fact, E2F-1 was shown to generate apoptosis by inhibiting antiapoptotic signals, including NF-KB (Phillips et al., 1999). Further, E2F-1 induces p53 activity through an indirect mechanism (Bates and Vousden, 1999); in fact, p53 regulation occurs largely at the level of protein stability. In a normal unstressed cell, p53 is maintained at a low level by a negative feedback loop in which p53 induces the transcription of $\mathrm{Mdm}-2$, a direct p53 target gene, which in turn binds to p53 and mediates its degradation (Kubbutat et al., 1997). In response to diverse stress stimuli, the cell stabilizes p53 by preventing Mdm-2-mediated degradation. In fact, it was recently reported that E2F-1 can stabilize p53 via the induction of the human tumor suppressor protein p14 ${ }^{\mathrm{ARF}}$ (Bates et al., 1998) (Fig. 6). p14 ${ }^{\mathrm{ARF}}$ directly binds to Mdm-2, preventing degradation of $\mathrm{p} 53$. In addition, depending on the cellular context, the activation of $p 53$ results in one of two different outcomes, including cell cycle arrest or apoptotic cell death (Schuler and Green, 2001). Interestingly, p53 has been an attractive target for study, since it can intervene at every major step in apoptotic pathways (Haupt et al., 2003).

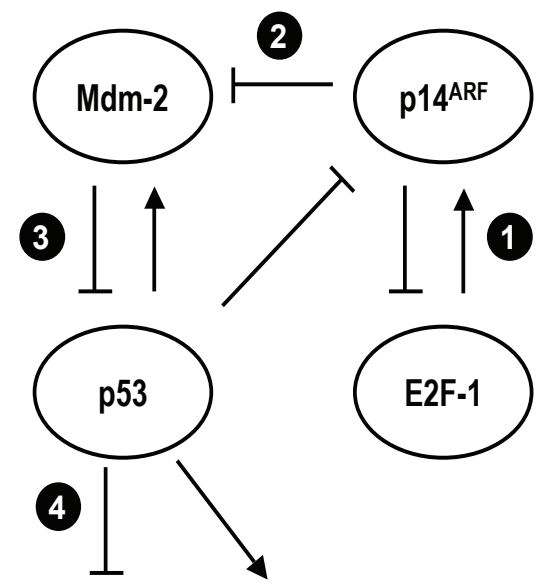

Antiapoptotic proteins
(e.g. Bcl-2)

Proapoptotic proteins (e.g. Bax, Noxa, Puma)

Fig. 6. E2F-1-induced apoptosis. E2F-1 stabilizes p53 via the induction of p14 ${ }^{\text {ARF }}$. E2F-1 induces p14 ${ }^{\text {ARF }}$ expression (1), which in turn directly binds to p53 inhibitor, Mdm-2 (2), preventing degradation of p53 (3). p53 promotes apoptosis by transcriptional modulation of the Bcl-2 family members, increasing the ratio of pro- to antiapoptotic proteins (4). $\rightarrow$, induction; -1 inhibition. 
The mechanism by which p53 signals members of the Bcl-2 family of proteins is not entirely understood. It has been shown that proapoptotic members of the Bcl2 family, such as Bax, Noxa or Puma are transcriptional targets of p53 (Miyashita and Reed, 1995; Schuler and Green, 2001; Thornborrow and Manfredi, 2001). In addition, p53 downregulates the antiapoptotic member $\mathrm{Bcl}-2$, thus inducing the release of apoptogenic factors from mitochondria (Miyashita et al., 1994). Notably, UDCA inhibits apoptosis of primary rat hepatocytes, by modulating gene expression of the E2F-1/Mdm-2/p53/ Bax apoptotic pathway, in a caspase-independent manner (Solá et al., 2003). In fact, E2F-1 transcriptional activation, Mdm-2 decrease, p53 stabilization and alterations in Bcl-2 family protein expression were abrogated by UDCA during hepatocyte apoptosis. Further, in the absence of a toxic stimulus, UDCA prevented induction of p53 and Bax by overexpression of E2F-1 and p53, respectively, indicating that UDCA specifically regulates different steps of this cell death pathway. Importantly, we have also demonstrated that UDCA modulates the E2F-1/Mdm-2/p53 apoptotic pathway via a nuclear steroid receptor (NSR)-dependent mechanism (Solá et al., 2004). Hepatocytes pretreated with UDCA upregulated NSR expression in association with reduced apoptosis. It was then shown that UDCA promoted NSR/chaperone dissociation, and subsequent NSR nuclear translocation. In fact, in the absence of ligand binding, NSR are primarily inactive and located within the cytosol in association with a variety of chaperone proteins. UDCA appears to directly interact with a specific region of the ligand binding domain of NSR, thereby mediating dissociation of NSR and translocation of an UDCA-NSR complex, and inhibition of apoptosis-related genes (Solá et al., 2005) (Fig. 7). Moreover, our studies demonstrated that UDCA does not increase NSR transactivation in reducing hepatocyte apoptosis, suggesting that UDCA may cooperate with other nuclear transcription factors to regulate gene transcription.

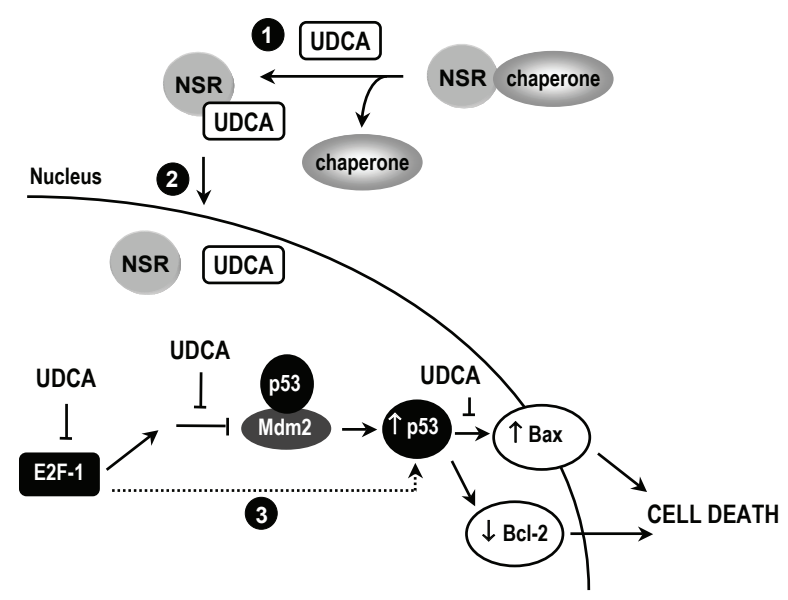

Fig. 7. Proposed model for the antiapoptotic function of UDCA. During hepatocyte apoptosis, UDCA appears to interact with a specific region of NSR ligand binding domain (1), leading to NSR/chaperone dissociation and subsequent nuclear translocation of both UDCA and NSR (2). The chaperone is frequently heat shock protein 90 (hsp90). Once in the nucleus, UDCA may inhibit the apoptotic cascade by regulating apoptoticrelated genes (3). $\rightarrow$, induction; $\multimap$, inhibition p53 was also recently shown to engage the mitochondrial membrane permeabilization by directly activating cytosolic Bax in a transcription-independent manner (Chipuk et al., 2004). Furthermore, p53 itself appears to act directly at the mitochondrial membrane. Recent findings showed that p53 promotes permeabilization of the outer mitochondrial membrane by forming complexes with $\mathrm{Bcl}-2$ and $\mathrm{Bcl}-\mathrm{x}_{\mathrm{L}}$ (Mihara et al., 2003). Importantly, p53 induces Apaf-1 expression through a response element within the Apaf-1 promoter (Robles et al., 2001). In addition, it activates the death receptor pathway of apoptosis by inducing the expression of three transmembrane proteins, including Fas, death receptor 5 (DR5) and p53 apoptosis effector related to PMP-22 (PERP). Curiously, a small molecule compound (2-[2-inimo-4,5,6,7-tetrahydrobenzothiazol-3-yl]-1-ptolylethanone) that inhibits wild type p53 (Komarov et al., 1999) may be a potential cytoprotective agent for preventing damage to normal tissues in patients receiving chemotherapy and/or radiation for tumors that lack functional p53.

The link between cell cycle and apoptosis has also been recognized in other proteins, such as c-Myc, Ras and cell cycle regulators including cyclin-dependent kinases (CDK) and cyclins (Vermeulen et al., 2003). The molecular events responsible for c-Myc-induced apoptosis are not well understood. c-Myc-induced apoptosis may involve either p53-dependent or -independent pathways. It has been shown that c-Myc transactivates the $p 53$ gene promoter and increases the half-life of p53 (Hermeking and Eick, 1994). In addition, c-Myc-induced apoptosis has been correlated with the Fas system (Wang et al., 1998), activation of Bax and cytochrome $c$ release (Soucie et al., 2001). Interestingly, Ras activates both the MAPK signaling cascade and the PI3K pathway, thus playing a role in the regulation of apoptosis (Adjei, 2001). In fact, Ras-mediated apoptosis proceeds through a MAPK pathway. The c-Jun N-terminal protein kinase (JNK) in turn could be triggered by the death receptor pathway or by cellular stress (Franklin and McCubrey, 2000). In the JNK pathway, Ras activates the MAPK kinase kinase MAPK/ERK kinase kinase (MEKK), which activates different MAPK kinases to phosphorylate the MAPK JNK. Active JNK phosphorylates the transcription factor C-Jun, which in turn is crucial for induction of several apoptotic genes (Leppa and Bohmann, 1999).

Finally, different cell cycle regulators, including Weel1, cdc27, p21, p27, pRb and CDK1 are targets for cleavage by caspases, indicating that cell cycle progression is significantly modulated during apoptosis (Jacotot et al., 2000). However, conflicting results exist regarding the role of CDKs in apoptosis. Some studies reported a proapoptotic activity, by showing that apoptosis-inducing agents such as staurosporine or caffeine induce CDK1 and CDK2 activity prior to cell death (Meikrantz et al., 1994), whereas dominant negative mutants of CDK1, CDK2 and CDK3 suppress apoptosis induced by staurosporine and TNF- $\alpha$ (Meikrantz and Schlegel, 1996). Taken together, induction of apoptosis depends on the cellular context where conflicting signals for cell proliferation and cell cycle arrest may result in cell death. 


\section{Conclusion}

Advances in understanding the molecular mechanisms of apoptosis provide the opportunity for therapeutic intervention in several diseases characterized by an imbalance of cell survival and death. Herein, we elucidated the main pathways, effectors and molecular interactions involved in the dynamic process of apoptosis. Theoretically, all drug targets can be addressed in multiple ways by modulating the activity of the target at the levels of DNA, mRNA, or protein. Nevertheless, we listed a number of potentially promising therapeutic approaches to either promote or repress apoptosis, some of which are already being tested in human clinical trials. As expected, ,the therapeutic approach for cancer is to trigger tumorselective cell death. A number of strategies are currently being envisioned for this purpose, including the use of chemical inhibitors or antisense experiments targeting survival pathways, such as IAPs, NF-kB or protein kinases. In addition, we are now observing a growing effort to design and develop new agents directed to offset the apoptosis process and improve the pharmacologic intervention for diseases associated with high levels of apoptosis. To this end, apoptosis-blocking proteins, such as caspases inhibitors, are attractive candidates. Moreover, UDCA and its conjugates, by acting as pleiotropic agents, may represent an effective treatment modality to diseases associated with increased levels of apoptosis. It remains to be determined as to the mechanism(s) by which UDCA regulates gene transcription. UDCA was visualized as aggregates in the nucleus of hepatocytes, indicating that the bile acid may either form complexes itself or interact with other protein complexes. Much like other bile acids, UDCA may have the affinity to directly bind to DNA. Nevertheless, UDCA should necessarily interact with transcriptional factors inside the nucleus in order to regulate gene expression. The transcription factor p53 may be a good candidate, since we have shown that the bile acid is able to suppress p53-induced Bax expression. Nevertheless, UDCA modulates the expression of the E2F-1 protein, as well as the expression of p53 itself, indicating that other transcription factors are similarly regulated. The next decade will almost certainly unveil the remarkable role of apoptosis-based therapies in the control of many human disorders.

\section{Acknowledgments}

Supported by grants POCI/SAU-MMO/57936/2004 and $\mathrm{POCl} / \mathrm{SAU}-\mathrm{FCF} / 62479 / 2004$ from Fundação para a Ciência e a Tecnologia (FCT), Lisbon, Portugal (to C.M.P.R.). S.S. was recipient of a postdoctoral fellowship (SFRH/BPD/20834/2004) from FCT. The authors thank all the members of the laboratory for critical reading of the manuscript.

\section{References}

Abraham, M.C., and Shaham, S. (2004). Death without caspases, caspases without death. Trends. Cell Biol. 14, 184-193.

Adams, J., Palombella, V.J., and Elliott, P.J. (2000). Proteasome inhibition: a new strategy in cancer treatment. Invest. New Drugs 18, 109-121.
Adjei, A.A. (2001). Blocking oncogenic Ras signaling for cancer therapy. J. Natl. Cancer Inst. 93, 1062-1074.

Ambrosini, G., Adida, C., and Altieri, D.C. (1997). A novel anti-apoptosis gene, survivin, expressed in cancer and lymphoma. Nat. Med. 3, 917-921.

Antonsson, B., Conti, F., Ciavatta, A., Montessuit, S., Lewis, S., Martinou, I., Bernasconi, L., Bernard, A., Mermod, J.J., Mazzei, G., et al. (1997). Inhibition of Bax channel-forming activity by Bcl-2. Science 277 , 370-372.

Antonsson, B., and Martinou, J.C. (2000). The Bcl-2 protein family. Exp. Cell Res. 256, 50-57.

Azzaroli, F., Mehal, W., Soroka, C.J., Wang, L., Lee, J., Crispe, N., and Boyer, J.L. (2002). Ursodeoxycholic acid diminishes Fas-ligand-induced apoptosis in mouse hepatocytes. Hepatology 36, 49-54.

Bates, S., Phillips, A.C., Clark, P.A., Stott, F., Peters, G., Ludwig, R.L., and Vousden, K.H. (1998). p14ARF links the tumour suppressors RB and p53. Nature 395, 124125.

Bates, S., and Vousden, K.H. (1999). Mechanisms of p53mediated apoptosis. Cell Mol. Life Sci. 55, 28-37.

Bayerdorffer, E., Mannes, G.A., Richter,W.O., Ochsenkuhn, T., Wiebecke, B., Kopcke, W., and Paumgartner, G. (1993). Increased serum deoxycholic acid levels in men with colorectal adenomas. Gastroenterology 104, 145-151.

Bergeron, L., Perez, G.I., Macdonald, G., Shi, L., Sun, Y., Jurisicova, A., Varmuza, S., Latham, K.E., Flaws, J.A., Salter, J.C., et al. (1998). Defects in regulation of apoptosis in caspase-2-deficient mice. Genes Dev. 12, 1304-1314.

Blagosklonny, M.V. (2000). Cell death beyond apoptosis. Leukemia 14, 1502-1508.

Bonni, A., Brunet, A., West, A.E., Datta, S.R., Takasu, M.A., and Greenberg, M.E. (1999). Cell survival promoted by the Ras-MAPK signaling pathway by transcriptiondependent and -independent mechanisms. Science 286, 1358-1362.

Bratton, S.B., Walker, G., Srinivasula, S.M., Sun, X.M., Butterworth, M., Alnemri, E.S., and Cohen, G.M. (2001). Recruitment, activation and retention of caspases-9 and -3 by Apaf- 1 apoptosome and associated XIAP complexes. EMBO J. 20, 998-1009.

Brunner, T., Mogil, R.J., LaFace, D., Yoo, N.J., Mahboubi, A., Echeverri, F., Martin, S.J., Force, W.R., Lynch, D.H., Ware, C.F., et al. (1995). Cell-autonomous Fas (CD95)/ Fas-ligand interaction mediates activation-induced apoptosis in T-cell hybridomas. Nature 373, 441-444.

Brustovetsky, N., and Klingenberg, M. (1996). Mitochondrial ADP/ATP carrier can be reversibly converted into a large channel by $\mathrm{Ca} 2+$. Biochemistry 35, 8483-8488.

Bull, A.W., Marnett, L.J., Dawe, E.J., and Nigro, N.D. (1983). Stimulation of deoxythymidine incorporation in the colon of rats treated intrarectally with bile acids and fats. Carcinogenesis 4, 207-210.

Cande, C., Vahsen, N., Garrido, C., and Kroemer, G. (2004). Apoptosis-inducing factor (AIF): caspaseindependent after all. Cell Death Differ. 11, 591-595.

Cardone, M.H., Roy, N., Stennicke, H.R., Salvesen, G.S., Franke, T.F., Stanbridge, E., Frisch, S., and Reed, J.C. 
(1998). Regulation of cell death protease caspase- 9 by phosphorylation. Science 282, 1318-1321.

Chen, J., Wu, W., Tahir, S.K., Kroeger, P.E., Rosenberg, S.H., Cowsert, L.M., Bennett, F., Krajewski, S., Krajewska, M., Welsh, K., et al. (2000). Down-regulation of survivin by antisense oligonucleotides increases apoptosis, inhibits cytokinesis and anchorageindependent growth. Neoplasia 2, 235-241.

Chipuk, J.E., Kuwana, T., Bouchier-Hayes, L., Droin, N.M., Newmeyer, D.D., Schuler, M., and Green, D.R. (2004). Direct activation of Bax by p53 mediates mitochondrial membrane permeabilization and apoptosis. Science 303, 1010-1014.

Clark, E.A., and Brugge, J.S. (1995). Integrins and signal transduction pathways: the road taken. Science 268 , 233-239.

Conradt, B., and Horvitz, H.R. (1998). The C. elegans protein EGL-1 is required for programmed cell death and interacts with the Bcl-2-like protein CED-9. Cell 93, 519-529.

Cory, S., Huang, D.C., and Adams, J.M. (2003). The Bcl-2 family: roles in cell survival and oncogenesis. Oncogene 22, 8590-8607.

Crompton, M., Virji, S., and Ward, J.M. (1998). Cyclophilin$\mathrm{D}$ binds strongly to complexes of the voltage-dependent anion channel and the adenine nucleotide translocase to form the permeability transition pore. Eur. J. Biochem. 258, 729-735.

Daniel, P.T. (2000). Dissecting the pathways to death. Leukemia 14, 2035-2044.

Datta, S.R., Brunet, A., and Greenberg, M.E. (1999). Cellular survival: a play in three Akts. Genes Dev. 13, 2905-2927.

Datta, S.R., Dudek, H., Tao, X., Masters, S., Fu, H., Gotoh, Y., and Greenberg, M.E. (1997). Akt phosphorylation of BAD couples survival signals to the cell-intrinsic death machinery. Cell 91, 231-241.

De Marchi, U., Campello, S., Szabo, I., Tombola, F., Martinou, J.C., and Zoratti, M. (2004). Bax does not directly participate in the $\mathrm{Ca}(2+)$-induced permeability transition of isolated mitochondria. J. Biol. Chem. 279, 37415-37422.

Degterev, A., Boyce, M., and Yuan, J. (2003). A decade of caspases. Oncogene 22, 8543-8567.

Degterev, A., Lugovskoy, A., Cardone, M., Mulley, B., Wagner, G., Mitchison, T., and Yuan, J. (2001). Identification of small-molecule inhibitors of interaction between the $\mathrm{BH} 3$ domain and $\mathrm{Bcl}-\mathrm{xL}$. Nat. Cell. Biol. 3, 173-182.

del Peso, L., Gonzalez-Garcia, M., Page, C., Herrera, R., and Nunez, G. (1997). Interleukin-3-induced phosphorylation of BAD through the protein kinase Akt. Science 278, 687-689.

Donovan, M., and Cotter, T.G. (2004). Control of mitochondrial integrity by $\mathrm{Bcl}-2$ family members and caspase-independent cell death. Biochim. Biophys. Acta 1644, 133-147.

Du, C., Fang, M., Li, Y., Li, L., and Wang, X. (2000). Smac, a mitochondrial protein that promotes cytochrome c-dependent caspase activation by eliminating IAP inhibition. Cell 102, 33-42.
Dubois-Dauphin, M., Frankowski, H., Tsujimoto, Y., Huarte, J., and Martinou, J.C. (1994). Neonatal motoneurons overexpressing the bcl-2 protooncogene in transgenic mice are protected from axotomy-induced cell death. Proc. Natl. Acad. Sci. USA. 91, 3309-3313.

Dyson, N. (1998). The regulation of E2F by pRB-family proteins. Genes Dev. 12, 2245-2262.

Ekert, P.G., Silke, J., Hawkins, C.J., Verhagen, A.M., and Vaux, D.L. (2001). DIABLO promotes apoptosis by removing MIHA/XIAP from processed caspase 9. J. Cell Biol. 152, 483-490.

Epand, R.F., Martinou, J.C., Montessuit, S., Epand, R.M., and Yip, C.M. (2002). Direct evidence for membrane pore formation by the apoptotic protein Bax. Biochem. Biophys. Res. Commun. 298, 744-749.

Eskes, R., Antonsson, B., Osen-Sand, A., Montessuit, S., Richter, C., Sadoul, R., Mazzei, G., Nichols, A., and Martinou, J.C. (1998). Bax-induced cytochrome $C$ release from mitochondria is independent of the permeability transition pore but highly dependent on Mg2+ ions. J. Cell Biol. 143, 217-224.

Eskes, R., Desagher, S., Antonsson, B., and Martinou, J.C. (2000). Bid induces the oligomerization and insertion of Bax into the outer mitochondrial membrane. Mol. Cell Biol. 20, 929-935.

Feng, Q., Li, P., Salamanca, C., Huntsman, D., Leung, P.C., and Auersperg, N. (2005). Caspase-1alpha is down-regulated in human ovarian cancer cells and the overexpression of caspase-1alpha induces apoptosis. Cancer Res. 65, 8591-8596.

Finucane, D.M., Bossy-Wetzel, E., Waterhouse, N.J., Cotter, T.G., and Green, D.R. (1999). Bax-induced caspase activation and apoptosis via cytochrome c release from mitochondria is inhibitable by $\mathrm{Bcl}-\mathrm{xL}$. J. Biol. Chem. 274, 2225-2233.

Franklin, R.A., and McCubrey, J.A. (2000). Kinases: positive and negative regulators of apoptosis. Leukemia 14, 2019-2034.

Gaur, U., and Aggarwal, B.B. (2003). Regulation of proliferation, survival and apoptosis by members of the TNF superfamily. Biochem. Pharmacol. 66, 14031408.

Ghosh, S., and Karin, M. (2002). Missing pieces in the NF-kappaB puzzle. Cell 109 Suppl, S81-96.

Goonesinghe, A., Mundy, E.S., Smith, M., KhosraviFar, R., Martinou, J.C., and Degli Esposti, M. (2005). Pro-apoptotic Bid induces membrane perturbation by inserting selected lysolipids into the bilayer. Biochem. J. 387, 109-118.

Gottlob, K., Majewski, N., Kennedy, S., Kandel, E., Robey, R.B., and Hay, N. (2001). Inhibition of early apoptotic events by Akt/PKB is dependent on the first committed step of glycolysis and mitochondrial hexokinase. Genes Dev. 15, 1406-1418.

Green, D.R., and Reed, J.C. (1998). Mitochondria and apoptosis. Science 281, 1309-1312.

Guo, H., Petrin, D., Zhang, Y., Bergeron, C., Goodyer, C.G., and LeBlanc, A.C. (2006). Caspase-1 activation of caspase- 6 in human apoptotic neurons. Cell Death Differ. 13, 285-292.

Guo, Y., Srinivasula, S.M., Druilhe, A., FernandesAlnemri, T., and Alnemri, E.S. (2002). Caspase-2 
induces apoptosis by releasing proapoptotic proteins from mitochondria. J. Biol. Chem. 277, 13430-13437.

Halestrap, A.P., and Brennerb, C. (2003). The adenine nucleotide translocase: a central component of the mitochondrial permeability transition pore and key player in cell death. Curr. Med. Chem. 10, 1507-1525.

Hall, H.H., Gu, G., Garcia-Anoveros, J., Gong, L., Chalfie, M., and Driscoll, M. (1997). Neuropathology of degenerative cell death in Caenorhabditis elegans. J. Neurosci. 17, 1033-1045.

Haupt, S., Berger, M., Goldberg, Z., and Haupt, Y. (2003). Apoptosis - the p53 network. J. Cell Sci. 116, 40774085.

Hermeking, H., and Eick, D. (1994). Mediation of c-Mycinduced apoptosis by p53. Science 265, 2091-2093.

Hofmann, A.F. (2002). Cholestatic liver disease: pathophysiology and therapeutic options. Liver 22 Suppl 2, 14-19.

Hsu, Y.T., Wolter, K.G., and Youle, R.J. (1997). Cytosolto-membrane redistribution of Bax and $\mathrm{Bcl}-\mathrm{X}(\mathrm{L})$ during apoptosis. Proc. Natl. Acad. Sci. USA. 94, 3668-3672.

Hunter, D.R., Haworth, R.A., and Southard, J.H. (1976). Relationship between configuration, function, and permeability in calcium-treated mitochondria. J. Biol. Chem. 251, 5069-5077.

Ishihara, Y., and Shimamoto, N. (2006). Involvement of endonuclease $G$ in nucleosomal DNA fragmentation under sustained endogenous oxidative stress. J. Biol. Chem. 281, 6726-6733.

Jacotot, E., Ferri, K.F., and Kroemer, G. (2000). Apoptosis and cell cycle: distinct checkpoints with overlapping upstream control. Pathol. Biol. (Paris) 48, 271-279.

James, D.I., Parone, P.A., Mattenberger, Y., and Martinou, J.C. (2003). hFis1, a novel component of the mammalian mitochondrial fission machinery. J. Biol. Chem. 278, 36373-36379.

Kaufmann, S.H., and Hengartner, M.O. (2001). Programmed cell death: alive and well in the new millennium. Trends Cell Biol. 11, 526-534.

Keene, C.D., Rodrigues, C.M., Eich, T., Chhabra, M.S., Steer, C.J., and Low, W.C. (2002). Tauroursodeoxycholic acid, a bile acid, is neuroprotective in a transgenic animal model of Huntington's disease. Proc. Natl. Acad. Sci. USA. 99, 10671-10676.

Keene, C.D., Rodrigues, C.M., Eich, T., Linehan-Stieers, C., Abt, A., Kren, B.T., Steer, C.J., and Low, W.C. (2001). A bile acid protects against motor and cognitive deficits and reduces striatal degeneration in the 3nitropropionic acid model of Huntington's disease. Exp. Neurol. 171, 351-360.

Kennedy, S.G., Kandel, E.S., Cross, T.K., and Hay, N. (1999). Akt/Protein kinase B inhibits cell death by preventing the release of cytochrome $\mathrm{C}$ from mitochondria. Mol. Cell Biol. 19, 5800-5810.

Kerr, J.F., Wyllie, A.H., and Currie, A.R. (1972). Apoptosis: a basic biological phenomenon with wide-ranging implications in tissue kinetics. Br. J. Cancer 26, 239257.

Kim, T.H., Zhao, Y., Barber, M.J., Kuharsky, D.K., and Yin, X.M. (2000). Bid-induced cytochrome c release is mediated by a pathway independent of mitochondrial permeability transition pore and Bax. J. Biol. Chem. 275, 39474-39481.

Komarov, P.G., Komarova, E.A., Kondratov, R.V., Christov-Tselkov, K., Coon, J.S., Chernov, M.V., and Gudkov, A.V. (1999). A chemical inhibitor of p53 that protects mice from the side effects of cancer therapy. Science 285, 1733-1737.

Kostic, V., Jackson-Lewis, V., de Bilbao, F., DuboisDauphin, M., and Przedborski, S. (1997). Bcl-2: prolonging life in a transgenic mouse model of familial amyotrophic lateral sclerosis. Science 277, 559-562.

Krammer, P.H. (1999). CD95(APO-1/Fas)-mediated apoptosis: live and let die. Adv. Immunol. 71, 163-210.

Kroemer, G. (2003). Mitochondrial control of apoptosis: an introduction. Biochem. Biophys. Res. Commun. 304, 433-435.

Kroemer, G., Petit, P., Zamzami, N., Vayssiere, J.L., and Mignotte, B. (1995). The biochemistry of programmed cell death. FASEB J. 9, 1277-1287.

Kroemer, G., and Reed, J.C. (2000). Mitochondrial control of cell death. Nat. Med. 6, 513-519.

Kroemer, G., Zamzami, N., and Susin, S.A. (1997). Mitochondrial control of apoptosis. Immunol. Today 18, 44-51.

Krueger, A., Baumann, S., Krammer, P.H., and Kirchhoff, S. (2001). FLICE-inhibitory proteins: regulators of death receptor-mediated apoptosis. Mol. Cell Biol. 21, 82478254.

Kubbutat, M.H., Jones, S.N., and Vousden, K.H. (1997). Regulation of p53 stability by Mdm2. Nature 387, 299303.

Lacour, S., Hammann, A., Wotawa, A., Corcos, L., Solary, E., and Dimanche-Boitrel, M.T. (2001). Anticancer agents sensitize tumor cells to tumor necrosis factorrelated apoptosis-inducing ligand-mediated caspase-8 activation and apoptosis. Cancer Res. 61, 1645-1651.

Lamkanfi, M., Kalai, M., and Vandenabeele, P. (2004). Caspase-12: an overview. Cell Death Differ. 11, 365368.

Lassus, P., Opitz-Araya, X., and Lazebnik, Y. (2002). Requirement for caspase-2 in stress-induced apoptosis before mitochondrial permeabilization. Science 297, 1352-1354.

Lee, B.I., Lee, D.J., Cho, K.J., and Kim, G.W. (2005). Early nuclear translocation of endonuclease $G$ and subsequent DNA fragmentation after transient focal cerebral ischemia in mice. Neurosci. Lett. 386, 23-27.

Lee, D., Long, S.A., Murray, J.H., Adams, J.L., Nuttall, M.E., Nadeau, D.P., Kikly, K., Winkler, J.D., Sung, C.M., Ryan, M.D., et al. (2001). Potent and selective nonpeptide inhibitors of caspases 3 and 7. J. Med. Chem. 44, 2015-2026.

Leppa, S., and Bohmann, D. (1999). Diverse functions of JNK signaling and C-Jun in stress response and apoptosis. Oncogene 18, 6158-6162.

Li, F., Ackermann, E.J., Bennett, C.F., Rothermel, A.L., Plescia, J., Tognin, S., Villa, A., Marchisio, P.C., and Altieri, D.C. (1999). Pleiotropic cell-division defects and apoptosis induced by interference with survivin function. Nat. Cell Biol. 1, 461-466. 
Li, H., Zhu, H., Xu, C.J., and Yuan, J. (1998). Cleavage of BID by caspase 8 mediates the mitochondrial damage in the Fas pathway of apoptosis. Cell 94, 491-501.

Li, L.Y., Luo, X., and Wang, X. (2001). Endonuclease G is an apoptotic DNase when released from mitochondria. Nature 412, 95-99.

Li, P., Allen, H., Banerjee, S., Franklin, S., Herzog, L., Johnston, C., McDowell, J., Paskind, M., Rodman, L., Salfeld, J., et al. (1995). Mice deficient in IL-1 betaconverting enzyme are defective in production of mature IL-1 beta and resistant to endotoxic shock. Cell $80,401-411$.

Luo, X., Budihardjo, I., Zou, H., Slaughter, C., and Wang, X. (1998). Bid, a Bcl2 interacting protein, mediates cytochrome c release from mitochondria in response to activation of cell surface death receptors. Cell 94 , 481-490.

Marchetti, P., Castedo, M., Susin, S.A., Zamzami, N., Hirsch, T., Macho, A., Haeffner, A., Hirsch, F., Geuskens, M., and Kroemer, G. (1996). Mitochondrial permeability transition is a central coordinating event of apoptosis. J. Exp. Med. 184, 1155-1160.

Marsden, V.S., O'Connor, L., O'Reilly, L.A., Silke, J., Metcalf, D., Ekert, P.G., Huang, D.C., Cecconi, F., Kuida, K., Tomaselli, K.J., et al. (2002). Apoptosis initiated by $\mathrm{Bcl}-2$-regulated caspase activation independently of the cytochrome c/Apaf-1/caspase-9 apoptosome. Nature 419, 634-637.

Meikrantz, W., Gisselbrecht, S., Tam, S.W., and Schlegel, R. (1994). Activation of cyclin A-dependent protein kinases during apoptosis. Proc. Natl. Acad. Sci. USA. 91, 3754-3758.

Meikrantz, W., and Schlegel, R. (1996). Suppression of apoptosis by dominant negative mutants of cyclindependent protein kinases. J. Biol. Chem. 271, 1020510209.

Mihara, M., Erster, S., Zaika, A., Petrenko, O., Chittenden, T., Pancoska, P., and Moll, U.M. (2003). p53 has a direct apoptogenic role at the mitochondria. Mol. Cell 11, 577-590.

Minn, A.J., Velez, P., Schendel, S.L., Liang, H., Muchmore, S.W., Fesik, S.W., Fill, M., and Thompson, C.B. (1997). Bcl-x(L) forms an ion channel in synthetic lipid membranes. Nature 385, 353-357.

Miramar, M.D., Costantini, P., Ravagnan, L., Saraiva, L.M., Haouzi, D., Brothers, G., Penninger, J.M., Peleato, M.L., Kroemer, G., and Susin, S.A. (2001). NADH oxidase activity of mitochondrial apoptosis-inducing factor. J. Biol. Chem. 276, 16391-16398.

Mittnacht, S. (1998). Control of pRB phosphorylation. Curr. Opin. Genet. Dev. 8, 21-27.

Miyashita, T., Krajewski, S., Krajewska, M., Wang, H.G., Lin, H.K., Liebermann, D.A., Hoffman, B., and Reed, J.C. (1994). Tumor suppressor p53 is a regulator of bcl-2 and bax gene expression in vitro and in vivo. Oncogene 9, 1799-1805

Miyashita, T., and Reed, J.C. (1995). Tumor suppressor p53 is a direct transcriptional activator of the human bax gene. Cell 80, 293-299.

Morishima, N., Nakanishi, K., Tsuchiya, K., Shibata, T., and Seiwa, E. (2004). Translocation of Bim to the endoplasmic reticulum (ER) mediates ER stress signaling for activation of caspase-12 during ER stressinduced apoptosis. J. Biol. Chem. 279, 50375-50381.

Nachmias, B., Ashhab, Y., and Ben-Yehuda, D. (2004). The inhibitor of apoptosis protein family (IAPs): an emerging therapeutic target in cancer. Semin. Cancer. Biol. 14, 231-243.

Nagata, S., and Golstein, P. (1995). The Fas death factor. Science 267, 1449-1456.

Nevins, J.R. (1998). Toward an understanding of the functional complexity of the E2F and retinoblastoma families. Cell Growth Differ. 9, 585-593.

Nur, E.K.A., Gross, S.R., Pan, Z., Balklava, Z., Ma, J., and Liu, L.F. (2004). Nuclear translocation of cytochrome c during apoptosis. J. Biol. Chem. 279, 24911-24914.

Ona, V.O., Li, M., Vonsattel, J.P., Andrews, L.J., Khan, S.Q., Chung, W.M., Frey, A.S., Menon, A.S., Li, X.J., Stieg, P.E., et al. (1999). Inhibition of caspase-1 slows disease progression in a mouse model of Huntington's disease. Nature 399, 263-267.

Ozes, O.N., Mayo, L.D., Gustin, J.A., Pfeffer, S.R., Pfeffer, L.M., and Donner, D.B. (1999). NF-kappaB activation by tumour necrosis factor requires the Akt serine-threonine kinase. Nature 401, 82-85.

Park, J., Leong, M.L., Buse, P., Maiyar, A.C., Firestone, G.L., and Hemmings, B.A. (1999). Serum and glucocorticoid-inducible kinase (SGK) is a target of the PI 3-kinase-stimulated signaling pathway. EMBO J. 18, 3024-3033.

Park, Y.C., Jeong, J.H., Park, K.J., Choi, H.J., Park, Y.M., Jeong, B.K., Higuchi, Y., and Yoo, Y.H. (2005). Sulindac activates nuclear translocation of AIF, DFF40 and endonuclease $\mathrm{G}$ but not induces oligonucleosomal DNA fragmentation in HT-29 cells. Life Sci. 77, 2059-2070.

Parone, P.A., James, D., and Martinou, J.C. (2002). Mitochondria: regulating the inevitable. Biochimie 84, 105-111.

Paroni, G., Henderson, C., Schneider, C., and Brancolini, C. (2002). Caspase-2 can trigger cytochrome $C$ release and apoptosis from the nucleus. J. Biol. Chem. 277, 15147-15161.

Petit, P.X., Susin, S.A., Zamzami, N., Mignotte, B., and Kroemer, G. (1996). Mitochondria and programmed cell death: back to the future. FEBS Lett. 396, 7-13.

Phillips, A.C., Ernst, M.K., Bates, S., Rice, N.R., and Vousden, K.H. (1999). E2F-1 potentiates cell death by blocking antiapoptotic signaling pathways. Mol. Cell 4, 771-781.

Phillips, A.C., and Vousden, K.H. (2001). E2F-1 induced apoptosis. Apoptosis 6, 173-182.

Poupon, R.E., Poupon, R., and Balkau, B. (1994). Ursodiol for the long-term treatment of primary biliary cirrhosis. The UDCA-PBC Study Group. N. Engl. J. Med. 330, 1342-1347.

Qiao, L., Yacoub, A., Studer, E., Gupta, S., Pei, X.Y., Grant, S., Hylemon, P.B., and Dent, P. (2002). Inhibition of the MAPK and PI3K pathways enhances UDCA-induced apoptosis in primary rodent hepatocytes. Hepatology 35, 779-789.

Ravagnan, L., Gurbuxani, S., Susin, S.A., Maisse, C., Daugas, E., Zamzami, N., Mak, T., Jaattela, M., Penninger, J.M., Garrido, C., and Kroemer, G. (2001). 
Heat-shock protein 70 antagonizes apoptosis-inducing factor. Nat. Cell Biol. 3, 839-843.

Reed, J.C. (2002). Apoptosis-based therapies. Nat. Rev. Drug Discov. 1, 111-121.

Roberts, D.L., Merrison, W., MacFarlane, M., and Cohen, G.M. (2001). The inhibitor of apoptosis protein-binding domain of Smac is not essential for its proapoptotic activity. J. Cell. Biol. 153, 221-228.

Robertson, J.D., Enoksson, M., Suomela, M., Zhivotovsky, B., and Orrenius, S. (2002). Caspase-2 acts upstream of mitochondria to promote cytochrome $c$ release during etoposide-induced apoptosis. J. Biol. Chem. 277, 29803-29809.

Robles, A.I., Bemmels, N.A., Foraker, A.B., and Harris, C.C. (2001). APAF-1 is a transcriptional target of p53 in DNA damage-induced apoptosis. Cancer Res. 61, 6660-6664.

Rodrigues, C.M.P., Fan, G., Ma, X., Kren, B.T., and Steer, C.J. (1998a). A novel role for ursodeoxycholic acid in inhibiting apoptosis by modulating mitochondrial membrane perturbation. J. Clin. Invest. 101, 27902799.

Rodrigues, C.M.P., Fan, G., Wong, P.Y., Kren, B.T., and Steer, C.J. (1998b). Ursodeoxycholic acid may inhibit deoxycholic acid-induced apoptosis by modulating mitochondrial transmembrane potential and reactive oxygen species production. Mol. Med 4, 165-178.

Rodrigues, C.M.P., Ma, X., Linehan-Stieers, C., Fan, G., Kren, B.T., and Steer, C.J. (1999). Ursodeoxycholic acid prevents cytochrome c release in apoptosis by inhibiting mitochondrial membrane depolarization and channel formation. Cell Death Differ. 6, 842-854.

Rodrigues, C.M.P., Solá, S., Nan, Z., Castro, R.E., Ribeiro, P.S., Low, W.C., and Steer, C.J. (2003a). Tauroursodeoxycholic acid reduces apoptosis and protects against neurological injury after acute hemorrhagic stroke in rats. Proc. Natl. Acad. Sci. USA. 100, 6087-6092.

Rodrigues, C.M.P., Solá, S., Sharpe, J.C., Moura, J.J., and Steer, C.J. (2003b). Tauroursodeoxycholic acid prevents Bax-induced membrane perturbation and cytochrome $\mathrm{C}$ release in isolated mitochondria. Biochemistry 42, 3070-3080.

Rodrigues, C.M.P., Spellman, S.R., Solá, S., Grande, A.W., Linehan-Stieers, C., Low, W.C., and Steer, C.J. (2002). Neuroprotection by a bile acid in an acute stroke model in the rat. J. Cereb. Blood Flow Metab. 22, 463-471.

Rodriguez, A., Oliver, H., Zou, H., Chen, P., Wang, X., and Abrams, J.M. (1999). Dark is a Drosophila homologue of Apaf-1/CED-4 and functions in an evolutionarily conserved death pathway. Nat. Cell Biol. 1, 272-279.

Rosen, A., and Casciola-Rosen, L. (1997). Macromolecular substrates for the ICE-like proteases during apoptosis. J. Cell Biochem. 64, 50-54.

Rothe, M., Pan, M.G., Henzel, W.J., Ayres, T.M., and Goeddel, D.V. (1995). The TNFR2-TRAF signaling complex contains two novel proteins related to baculoviral inhibitor of apoptosis proteins. Cell 83, 1243-1252.

Roucou, X., Rostovtseva, T., Montessuit, S., Martinou, J.C., and Antonsson, B. (2002). Bid induces cytochrome c-impermeable Bax channels in liposomes. Biochem. J. 363, 547-552.

Rubin, R.A., Kowalski, T.E., Khandelwal, M., and Malet, P.F. (1994). Ursodiol for hepatobiliary disorders. Ann. Intern. Med. 121, 207-218.

Rust, C., Karnitz, L.M., Paya, C.V., Moscat, J., Simari, R.D., and Gores, G.J. (2000). The bile acid taurochenodeoxycholateactivatesaphosphatidylinositol 3-kinase-dependent survival signaling cascade. J. Biol. Chem. 275, 20210-20216.

Sakahira, H., Enari, M., and Nagata, S. (1998). Cleavage of CAD inhibitor in CAD activation and DNA degradation during apoptosis. Nature 391, 96-99.

Schendel, S.L., Azimov, R., Pawlowski, K., Godzik, A., Kagan, B.L., and Reed, J.C. (1999). Ion channel activity of the $\mathrm{BH} 3$ only $\mathrm{Bcl}-2$ family member, BID. J. Biol. Chem. 274, 21932-21936.

Schoemaker, M.H., Conde de la Rosa, L., BuistHoman, M., Vrenken, T.E., Havinga, R., Poelstra, K., Haisma, H.J., Jansen, P.L., and Moshage, H. (2004). Tauroursodeoxycholic acid protects rat hepatocytes from bile acid-induced apoptosis via activation of survival pathways. Hepatology 39, 1563-1573.

Schuler, M., and Green, D.R. (2001). Mechanisms of p53-dependent apoptosis. Biochem. Soc. Trans. 29, 684-688.

Sharpe, J.C., Arnoult, D., and Youle, R.J. (2004). Control of mitochondrial permeability by Bcl-2 family members. Biochim. Biophys. Acta 1644, 107-113.

Shi, Y. (2002). Mechanisms of caspase activation and inhibition during apoptosis. Mol. Cell 9, 459-470.

Shi, Y. (2004). Caspase activation: revisiting the induced proximity model. Cell 117, 855-858.

Silke, J., Kratina, T., Ekert, P.G., Pakusch, M., and Vaux, D.L. (2004). Unlike Diablo/smac, Grim promotes global ubiquitination and specific degradation of $X$ chromosome-linked inhibitor of apoptosis (XIAP) and neither cause apoptosis. J. Biol. Chem. 279, 43134321.

Solá, S., Amaral, J.D., Castro, R.E., Ramalho, R.M., Borralho, P.M., Kren, B.T., Tanaka, H., Steer, C.J., and Rodrigues, C.M.P. (2005). Nuclear translocation of UDCA by the glucocorticoid receptor is required to reduce TGF-beta1-induced apoptosis in rat hepatocytes. Hepatology 42, 925-934.

Solá, S., Castro, R.E., Kren, B.T., Steer, C.J., and Rodrigues, C.M.P. (2004). Modulation of nuclear steroid receptors by ursodeoxycholic acid inhibits TGFbeta1-induced E2F-1/p53-mediated apoptosis of rat hepatocytes. Biochemistry 43, 8429-8438.

Solá, S., Castro, R.E., Laires, P.A., Steer, C.J., and Rodrigues, C.M.P. (2003a). Tauroursodeoxycholic acid prevents amyloid-beta peptide-induced neuronal death via a phosphatidylinositol 3-kinase-dependent signaling pathway. Mol. Med. 9, 226-234.

Solá, S., Ma, X., Castro, R.E., Kren, B.T., Steer, C.J., and Rodrigues, C.M.P. (2003b). Ursodeoxycholic acid modulates E2F-1 and p53 expression through a caspaseindependent mechanism in transforming growth factor beta1-induced apoptosis of rat hepatocytes. J. Biol. Chem. 278, 48831-48838. 
Sorenson, C.M. (2004). Bcl-2 family members and disease. Biochim. Biophys. Acta 1644, 169-177.

Soucie, E.L., Annis, M.G., Sedivy, J., Filmus, J., Leber, B., Andrews, D.W., and Penn, L.Z. (2001). Myc potentiates apoptosis by stimulating Bax activity at the mitochondria. Mol. Cell Biol. 21, 4725-4736

Sporn, M.B., Suh, N., and Mangelsdorf, D.J. (2001). Prospects for prevention and treatment of cancer with selective PPARgamma modulators (SPARMs). Trends Mol. Med. 7, 395-400.

Srinivasula, S.M., Ahmad, M., Fernandes-Alnemri, T., and Alnemri, E.S. (1998). Autoactivation of procaspase-9 by Apaf-1-mediated oligomerization. Mol. Cell 1, 949957.

Susin, S.A., Lorenzo, H.K., Zamzami, N., Marzo, I., Snow, B.E., Brothers, G.M., Mangion, J., Jacotot, E., Costantini, P., Loeffler, M., et al. (1999). Molecular characterization of mitochondrial apoptosis-inducing factor. Nature 397, 441-446.

Takahashi, R., Deveraux, Q., Tamm, I., Welsh, K., AssaMunt, N., Salvesen, G.S., and Reed, J.C. (1998). A single BIR domain of XIAP sufficient for inhibiting caspases. J. Biol. Chem. 273, 7787-7790.

Thornberry, N.A., and Lazebnik, Y. (1998). Caspases: enemies within. Science 281, 1312-1316.

Thornborrow, E.C., and Manfredi, J.J. (2001). The tumor suppressor protein p53 requires a cofactor to activate transcriptionally the human BAX promoter. J. Biol. Chem. 276, 15598-15608.

Toker, A., and Cantley, L.C. (1997). Signalling through the lipid products of phosphoinositide-3-OH kinase. Nature 387, 673-676.

Tsujimoto, Y., Gorham, J., Cossman, J., Jaffe, E., and Croce, C.M. (1985). The $t(14 ; 18)$ chromosome translocations involved in B-cell neoplasms result from mistakes in VDJ joining. Science 229, 1390-1393.

Tsujimoto, Y., and Shimizu, S. (2002). The voltagedependent anion channel: an essential player in apoptosis. Biochimie 84, 187-193.

Tsuruta, F., Masuyama, N., and Gotoh, Y. (2002). The phosphatidylinositol 3-kinase (PI3K)-Akt pathway suppresses Bax translocation to mitochondria. J. Biol. Chem. 277, 14040-14047.

Tzung, S.P., Kim, K.M., Basanez, G., Giedt, C.D., Simon, J., Zimmerberg, J., Zhang, K.Y., and Hockenbery, D.M. (2001). Antimycin A mimics a cell-death-inducing Bcl-2 homology domain 3. Nat. Cell Biol. 3, 183-191.

van Gurp, M., Festjens, N., van Loo, G., Saelens, X., and Vandenabeele, P. (2003). Mitochondrial intermembrane proteins in cell death. Biochem. Biophys. Res. Commun. 304, 487-497. van Loo, G., Schotte, P., van Gurp, M., Demol, H., Hoorelbeke, B., Gevaert, K., Rodriguez, I., Ruiz-Carrillo, A., Vandekerckhove, J., Declercq, W., et al. (2001). Endonuclease G: a mitochondrial protein released in apoptosis and involved in caspase-independent DNA degradation. Cell Death Differ. 8, 1136-1142.

Verhagen, A.M., Silke, J., Ekert, P.G., Pakusch, M., Kaufmann, H., Connolly, L.M., Day, C.L., Tikoo, A., Burke, R., Wrobel, C., et al. (2002). HtrA2 promotes cell death through its serine protease activity and its ability to antagonize inhibitor of apoptosis proteins. J. Biol. Chem. 277, 445-454.

Vermeulen, K., Berneman, Z.N., and Van Bockstaele, D.R. (2003). Cell cycle and apoptosis. Cell Prolif. 36, 165-175.

Vieira, H.L., Haouzi, D., El Hamel, C., Jacotot, E., Belzacq, A.S., Brenner, C., and Kroemer, G. (2000). Permeabilization of the mitochondrial inner membrane during apoptosis: impact of the adenine nucleotide translocator. Cell Death Differ. 7, 1146-1154.

Von Ahsen, O., Waterhouse, N.J., Kuwana, T., Newmeyer, D.D., and Green, D.R. (2000). The 'harmless' release of cytochrome c. Cell Death Differ. 7, 1192-1199.

Vucic, D., Stennicke, H.R., Pisabarro, M.T., Salvesen, G.S., and Dixit, V.M. (2000). ML-IAP, a novel inhibitor of apoptosis that is preferentially expressed in human melanomas. Curr. Biol. 10, 1359-1366.

Wang, R., Brunner, T., Zhang, L., and Shi, Y. (1998). Fungal metabolite FR901228 inhibits c-Myc and Fas ligand expression. Oncogene 17, 1503-1508.

Yin, X.M., Oltvai, Z.N., and Korsmeyer, S.J. (1994). BH1 and $\mathrm{BH} 2$ domains of $\mathrm{Bcl}-2$ are required for inhibition of apoptosis and heterodimerization with Bax. Nature 369, 321-323.

Yuan, J., Shaham, S., Ledoux, S., Ellis, H.M., and Horvitz, H.R. (1993). The C. elegans cell death gene ced-3 encodes a protein similar to mammalian interleukin-1 beta-converting enzyme. Cell 75, 641-652.

Zamzami, N., Susin, S.A., Marchetti, P., Hirsch, T., Gomez-Monterrey, I., Castedo, M., and Kroemer, G. (1996). Mitochondrial control of nuclear apoptosis. J. Exp. Med. 183, 1533-1544.

Zheng, T.S., Hunot, S., Kuida, K., and Flavell, R.A. (1999). Caspase knockouts: matters of life and death. Cell Death Differ. 6, 1043-1053.

Zoratti, M., and Szabo, I. (1995). The mitochondrial permeability transition. Biochim. Biophys. Acta 1241, 139-176.

Zou, H., Henzel, W.J., Liu, X., Lutschg, A., and Wang, X. (1997). Apaf-1, a human protein homologous to $C$. elegans CED-4, participates in cytochrome c-dependent activation of caspase-3. Cell 90, 405-413. 


\section{Further Reading}

Caister Academic Press is a leading academic publisher of advanced texts in microbiology, molecular biology and medical research. Full details of all our publications at caister.com

- MALDI-TOF Mass Spectrometry in Microbiology Edited by: M Kostrzewa, S Schubert (2016) www.caister.com/malditof

- Aspergillus and Penicillium in the Post-genomic Era Edited by: RP Vries, IB Gelber, MR Andersen (2016) www.caister.com/aspergillus2

- The Bacteriocins: Current Knowledge and Future Prospects Edited by: RL Dorit, SM Roy, MA Riley (2016)

www.caister.com/bacteriocins

- Omics in Plant Disease Resistance Edited by: V Bhadauria (2016) www.caister.com/opd

- Acidophiles: Life in Extremely Acidic Environments Edited by: R Quatrini, DB Johnson (2016) www.caister.com/acidophiles

- Climate Change and Microbial Ecology: Current Research and Future Trend

Edited by: J Marxsen (2016)

www.caister.com/climate

- Biofilms in Bioremediation: Current Research and Emerging Technologies

Edited by: G Lear (2016)

www.caister.com/biorem

- Microalgae: Current Research and Applications Edited by: MN Tsaloglou (2016) www.caister.com/microalgae

- Gas Plasma Sterilization in Microbiology: Theory, Applications, Pitfalls and New Perspectives Edited by: H Shintani, A Sakudo (2016) www.caister.com/gasplasma

- Virus Evolution: Current Research and Future Directions Edited by: SC Weaver, M Denison, M Roossinck, et al. (2016) www.caister.com/virusevol

- Arboviruses: Molecular Biology, Evolution and Control Edited by: N Vasilakis, DJ Gubler (2016) www.caister.com/arbo

- Shigella: Molecular and Cellular Biology Edited by: WD Picking, WL Picking (2016) www.caister.com/shigella

-Aquatic Biofilms: Ecology, Water Quality and Wastewater Treatment

Edited by: AM Romaní, H Guasch, MD Balaguer (2016)

www.caister.com/aquaticbiofilms

- Alphaviruses: Current Biology

Edited by: S Mahalingam, L Herrero, B Herring (2016)

www.caister.com/alpha

- Thermophilic Microorganisms

Edited by: F Li (2015)

www.caister.com/thermophile
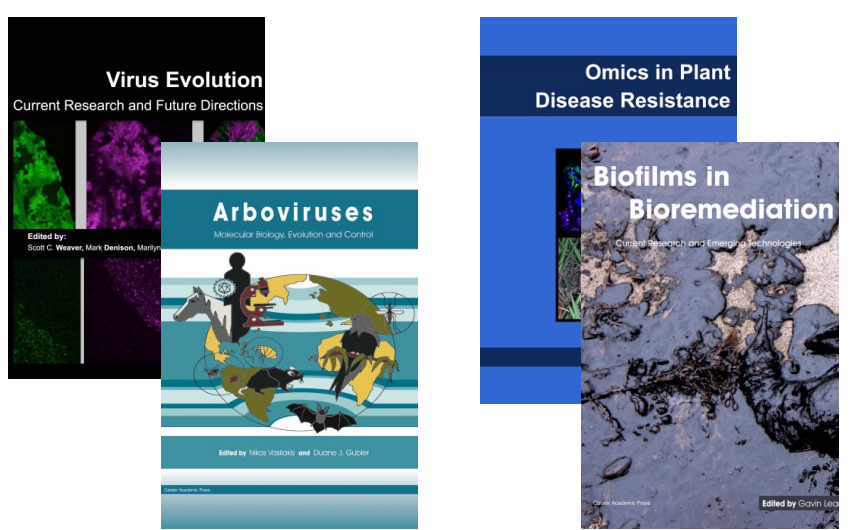
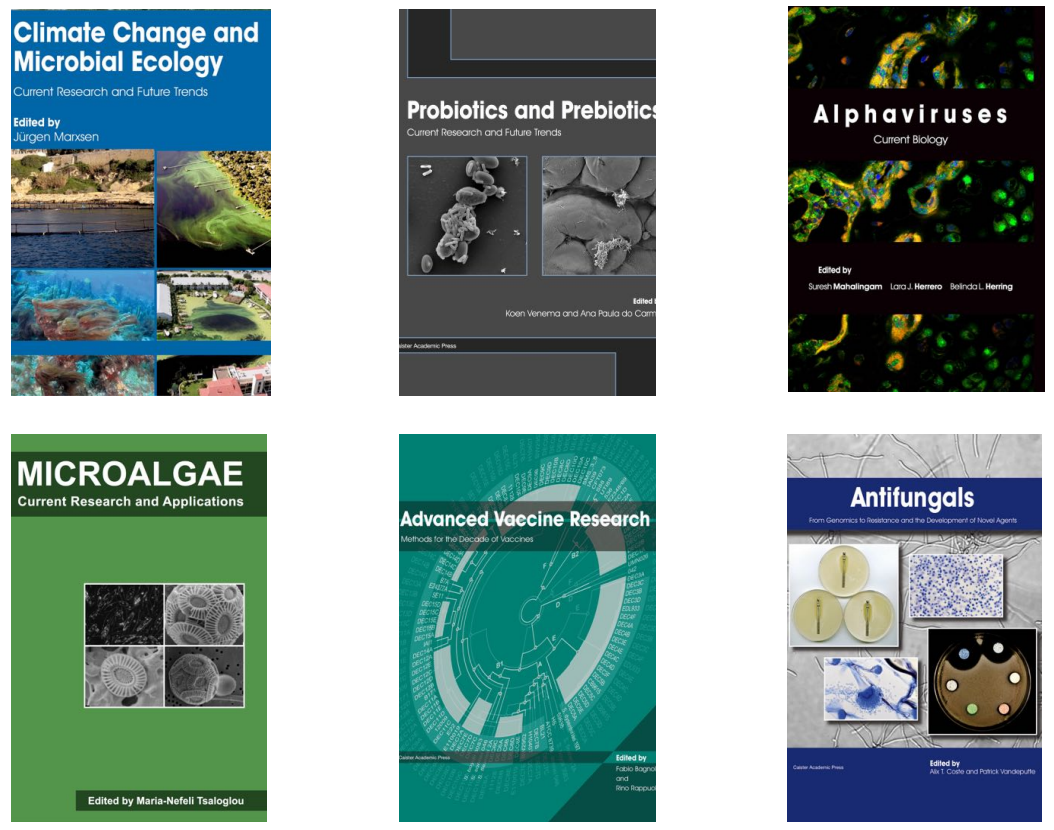

- Flow Cytometry in Microbiology: Technology and Applications Edited by: MG Wilkinson (2015) www.caister.com/flow

- Probiotics and Prebiotics: Current Research and Future Trends Edited by: K Venema, AP Carmo (2015) www.caister.com/probiotics

- Epigenetics: Current Research and Emerging Trends Edited by: BP Chadwick (2015) www.caister.com/epigenetics2015

- Corynebacterium glutamicum: From Systems Biology to Biotechnological Applications

Edited by: A Burkovski (2015)

www.caister.com/cory2

- Advanced Vaccine Research Methods for the Decade of Vaccines

Edited by: F Bagnoli, R Rappuoli (2015)

www.caister.com/vaccines

- Antifungals: From Genomics to Resistance and the Development of Novel Agents

Edited by: AT Coste, P Vandeputte (2015)

www.caister.com/antifungals

- Bacteria-Plant Interactions: Advanced Research and Future Trends Edited by: J Murillo, BA Vinatzer, RW Jackson, et al. (2015) www.caister.com/bacteria-plant

\section{- Aeromonas}

Edited by: J Graf (2015)

www.caister.com/aeromonas

- Antibiotics: Current Innovations and Future Trends

Edited by: S Sánchez, AL Demain (2015)

www.caister.com/antibiotics

- Leishmania: Current Biology and Contro Edited by: S Adak, R Datta (2015) www.caister.com/leish2

- Acanthamoeba: Biology and Pathogenesis (2nd edition) Author: NA Khan (2015)

www.caister.com/acanthamoeba2

- Microarrays: Current Technology, Innovations and Applications Edited by: Z He (2014)

www.caister.com/microarrays2

- Metagenomics of the Microbial Nitrogen Cycle: Theory, Methods and Applications

Edited by: D Marco (2014)

www.caister.com/n2 